\title{
Differences in the Value Relevance of Identifiable Intangible Assets Acquired in Business Combinations
}

August 2019

\begin{abstract}
Some investors assert there are weaknesses in the current accounting model for business combinations that limit the usefulness of information reported for acquired identifiable intangibles. Organically replaced intangible assets require future ongoing expenditures to maintain or enhance their value, creating uncertainty about the amount and timing of future cash flows. Wasting intangible assets have identifiable revenue streams that do not require future investment and often have definite lives that are legally or contractually determined. The current accounting model for business combinations also requires recognition of identifiable intangibles that are not strategically important sources of economic benefits from the acquisition. Motivated by these claims, we develop testable hypotheses and examine differences in the associations between post-acquisition equity prices and different types of acquired intangibles. We predict and find that both wasting and organically replaced intangibles are positively associated with post-acquisition equity prices. However, we predict and find that the association is less positive for organically replaced intangibles than wasting intangibles. In addition, we predict and find that organically replaced intangibles exhibit a similar association with equity prices to goodwill. We also predict and find that strategically important intangibles are positively associated with post-acquisition equity prices, but find no association for other intangibles. Our findings highlight how differences in the underlying economic characteristics of acquired intangibles are reflected in the usefulness of financial reporting information for business combinations.
\end{abstract}

Keywords: Mergers and acquisitions, intangible assets, purchase price allocations, fair value JEL Classification: D82, G34, M41 


\section{INTRODUCTION}

This research investigates whether acquisition date fair value measurements of identifiable intangible assets acquired in business combinations are relevant and faithful representations of the expected amount, timing, and uncertainty of future cash flows to the entity. Under Statement of Financial Accounting Standards (SFAS) No. 141R (FASB 2007) and Accounting Standards Codification Topic 805, Business Combinations, acquiring firms must recognize and measure all identifiable assets and liabilities at acquisition date fair values. However, for the case of identifiable intangible assets (i.e., non-financial assets that lack physical substance), the acquisition method of accounting results in two accounting problems that some investors assert limit the usefulness of the information provided under the current financial reporting model ( $\mathrm{PwC}$ 2007; Financial Reporting Council (FRC) 2014).

The first problem that arises is some identifiable intangible assets require future ongoing expenditures to maintain or enhance their value. These expenditures create uncertainty about the amount and timing of future cash flows, and therefore diminish the relation between future cash flows and acquisition date fair values. For instance, investors raise concerns that the value of brands and tradenames depend on ongoing expenditures, such as advertising and promotion, over an indefinite and uncertain horizon. Moreover, investors have difficulty identifying and disentangling the future cash flows related to the intangible asset acquired on the acquisition date and the additional post-acquisition expenditures incurred to maintain or enhance its value. Investors refer to intangible assets that require ongoing expenditures to maintain or enhance their value as organically replaced (FRC 2014).

Other intangible assets have identifiable revenue streams that do not require future investment and often have definite lives that are legally or contractually determined. Compared to organically 
replaced intangibles, there is less uncertainty about the amount and timing of future cash flows associated with these assets, including those related to future revenue streams. For example, a patented pharmaceutical has a legally defined limit to the period over which a firm has an exclusive right to sell that pharmaceutical technology. In addition, revenues that arise from the sale of a patented pharmaceutical can be separately identified from other cash flows, and prior to patent expiration, do not require additional investment. Investors refer to intangible assets with identifiable revenue streams that do not require future investment often with legally or contractually determined useful lives, as wasting intangible assets. Therefore, investors claim that acquisition date fair values of wasting intangibles are more decision useful than organically replaced intangibles (FRC 2014).

The second accounting problem arises from application of the identifiability criterion under ASC 805. When the Financial Accounting Standards Board (FASB) issued SFAS 141R (FASB 2007), it used the identifiability criterion to reduce the magnitude of goodwill balances and increase the amount of information available to investors about the nature of identifiable intangible assets acquired in business combinations. The FASB believed it more important to recognize more identifiable intangible assets in SFAS 141R because SFAS 142 (FASB 2001b) changed the methods to account subsequently for intangible assets, introducing significant differences in amortization and/or impairment methods used for identifiable intangible assets and goodwill. ${ }^{1}$ ASC 805 requires firms to recognize at fair value in the balance sheet identifiable intangible assets acquired in a business combination that either are separable from the entity (i.e., could be sold or

\footnotetext{
${ }^{1}$ Identifiable intangible assets with definite useful lives are required to be amortized and impaired to fair value when the asset's carrying value exceeds an estimate of its' undiscounted future cash flows. Identifiable intangible assets with indefinite useful lives are not amortized but only impaired when the asset's carrying value exceeds an estimate of its' fair value. Unidentifiable intangible assets (goodwill) are also not amortized but impaired when the reporting unit's carrying amount exceeds its' fair value (current U.S. GAAP codified and active in ASC Topic 350, Intangibles - Goodwill and Other, as of August 8, 2019).
} 
licensed to a third party) or have legally enforceable rights. Therefore, the current financial reporting model sometimes requires recognition of assets that are not of strategic importance, which is of little informational use to investors (PwC 2007; FRC 2014). We also posit that the identifiability criterion can result in recognition of intangibles that do not meet the definition of an asset in the Conceptual Framework because the definition does not consider whether an item is separable from the entity (FASB 1985).

The Conceptual Framework defines an asset in terms of three primary attributes: (1) probable future economic benefit (2) obtained or controlled by the entity by excluding others' access to the benefit and (3) the benefit is the result of past transactions or events (FASB 1985). Consider a customer relationship asset recognized in a business combination comprised of customers' personal information that enables a firm to generate repeat sales in the future and that the customer information can be sold separately. There is clearly a probable economic benefit related to future sales; however, it is not clear whether the entity can exclude others' access to the benefits even though the personal information can be sold separately.

To provide evidence on our research question, we obtain a proprietary dataset containing information on acquiring firms' acquisition date fair value estimates of identifiable intangibles reported by public U.S. firms. To our knowledge, this dataset is the most comprehensive source of data on acquired intangible assets, comprised of more than 3,500 M\&A transactions completed between 2009 and 2016. From this dataset, we are able to link 2,980 deals to 1,547 unique U.S. firms covered on Compustat and CRSP. On average, total assets acquired within the sample of deals is about $\$ 1.1$ billion with $31 \%$ of total assets acquired classified as identifiable intangibles. On an aggregate basis, the sample represents approximately $\$ 3.2$ trillion of U.S. M\&A activity resulting in the addition of more than $\$ 670$ billion in identifiable intangible assets to firms' balance 
sheets. These data allow us to make inferences about an economically significant sample of identifiable intangible assets recognized in firms' financial statements over the last 10 years.

Our research design follows prior studies from the value relevance literature that examine the association of stock prices with earnings and book values (see Barth, Beaver, and Landsman 2001). Following this line of research, we use stock prices as a summary measure of investors' consensus beliefs about the amount, timing, and uncertainty of future cash flows to the firm. In our setting, this research design provides a framework to test whether identifiable intangibles reported in firms' purchase price allocation disclosures are relevant and faithful representations of investors' consensus beliefs about the amount, timing, and uncertainty of future cash flows expected from those assets. We also are able to draw inferences about differences in investors' consensus beliefs and the information reflected across different types of identifiable intangibles reported in firms' purchase price allocation disclosures.

Our first set of hypotheses assesses the value relevance of wasting and organically replaced identifiable intangible assets. First, because fair value provides an estimate of the discounted future cash flows to the entity from both wasting and organically replaced intangible assets acquired in a business combination, we predict that both wasting and organically replaced identifiable intangible assets have a positive association with equity prices. Second, we predict that wasting identifiable intangible assets have a more positive association with equity prices than organically replaced identifiable intangible assets. This prediction follows from the idea that information reported for wasting intangibles is a more relevant and faithful representation of the future cash flows to an entity, related to that asset, than it is for organically replaced identifiable intangible assets. This arises because the purchase price more completely reflects the totality of expected future cash flows from a wasting asset that does not require additional expenditures to maintain or enhance its 
value. Similar to organically replaced intangibles, goodwill also lacks an identifiable cash flow stream and requires continuing investments to integrate the firms' operations and realize expected synergies. Therefore, we predict that organically replaced intangibles and goodwill will exhibit similar associations with post-acquisition equity values.

We define organically replaced intangibles as those that require ongoing investment to maintain or enhance their value. Therefore, we classify customer-related intangibles, trademarks, and tradenames, as organically replaced intangibles because the value of these assets depends on future expenditures (e.g., promotion and marketing). We also classify in-process R\&D as an organically replaced intangible due to the ongoing nature of the underlying $R \& D$ activities related to these assets. We classify the remaining types of identifiable intangibles in our sample as wasting, which mostly consists of developed technologies (e.g., patents) and contract-related intangibles. These assets have identifiable revenue streams that do not require significant ongoing investments to maintain or enhance their cash flow generating ability. Our results provide support for our predictions. We find that both wasting and organically replaced intangible assets exhibit positive and significant associations with post-acquisition equity values. However, we find that the association for organically replaced intangibles is less positive than wasting intangibles, consistent with differences in the usefulness of information reflected in investors' consensus beliefs across these types of intangibles. In addition, we also find no difference in the associations between equity prices with organically replaced intangibles and goodwill.

Our second set of hypotheses assesses the value relevance of strategically important versus other identifiable intangible assets. Again, we predict that both strategically important and other identifiable intangible assets have positive associations with equity prices because fair value provides an estimate of the discounted future cash flows to the entity from both of these types of 
identifiable intangible assets. However, we predict that the most strategically important identifiable intangible assets have stronger associations with equity prices than other identifiable intangible assets. This hypothesis follows from the idea that the identifiability criterion potentially requires firms to recognize assets that are of little strategic importance.

Considering the definition of an asset in the FASB Conceptual Framework, we focus on the likelihood that an identifiable intangible asset is a primary source of future economic benefit in a given deal. We use multiple methods to classify identifiable intangibles as strategically important. First, we classify identifiable intangible assets as strategically important when the identifiable intangible as a percentage of total assets acquired is above the mean of that ratio in the full sample of identifiable intangibles. Second, we classify identifiable intangible assets as strategically important when the identifiable intangible as a percentage of total assets acquired is above the industry-adjusted mean of that ratio in the full sample of identifiable intangibles. The underlying assumption for these classifications is that identifiable intangible assets representing the economic value-drivers for the acquisition likely account for a larger percentage of total assets acquired. This approach also allows us to capture heterogeneity across firms and industries among the types of intangibles that are most likely to be strategically important. For example, our classification methodology most frequently classifies developed technologies and in-process $R \& D$ as strategically important in high-tech and pharmaceutical industries, whereas customer-related intangibles are classified most often as strategically important in service industries (e.g., entertainment, telecommunications, insurance).

Our tests show a positive and statistically significant association between strategically important intangibles and post-acquisition equity prices. In contrast, we find no association between other identifiable intangible assets and equity prices. These results are consistent with 
investors' claims that financial reporting information about identifiable intangibles is relevant when the asset is related to the strategic objectives for the acquisition, but that information for other intangibles is not relevant (PwC 2007; FRC 2014). Our inferences about wasting and organically replaced intangibles continue to hold in a set of robustness tests that address potential alternative explanations for our findings, including management reporting incentives, and alternative classifications of wasting and organically replaced intangibles.

Our final set of tests build on our findings related to investors' consensus beliefs reflected in equity prices about wasting, organically replaced, and strategically important intangibles. We conduct cross-sectional tests by partitioning wasting and organically replaced intangibles within the strategic importance classifications. In this analysis, we find that only strategically important identifiable intangible assets are positively associated with post-acquisition equity prices. Within the cross-section of strategically important identifiable intangible assets, organically replaced intangible assets also exhibit a less positive association with equity prices than wasting intangible assets. Neither wasting nor organically replaced intangibles are associated with equity prices when these assets are not strategically important.

Our research makes three primary contributions. First, a growing body of research examines whether intangible assets capitalized on the balance sheet are value relevant (see Wyatt 2008 for a review). ${ }^{2}$ Most of these studies focus on the value relevance of either aggregate identifiable

\footnotetext{
${ }^{2}$ The two most closely related studies to ours are Bauman and Shaw (2018) and McInnis and Monsen (2019), who examine identifiable intangible assets in recent U.S. samples. Bauman and Shaw (2018) focus on customer-related intangible assets and find they are associated with equity prices. We consider a broader set of identifiable intangible assets and differences in value relevance amongst those assets. McInnis and Monsen (2019) focus on accounting measurement uncertainty, and find identifiable intangibles are associated with future operating cash flows primarily in cross-sections where they argue measurement uncertainty is low. Instead of measurement uncertainty, we examine how the characteristics of wasting, organically replaced, and strategic importance are reflected in postacquisition equity prices.
} 
intangible assets or individual identifiable intangible assets by themselves (e.g., patents, customerrelated intangibles). Studies in this area generally find that balance sheet intangible assets are value relevant, and some report that the value relevance of certain balance sheet intangibles varies crosssectionally with characteristics of the firm and its information environment. In contrast, we contribute to this line of research by investigating cross-sectional differences in the underlying economic characteristics of identifiable intangible assets. Our findings provide evidence that the value relevance of identifiable intangible assets differs predictably with economic characteristics related to those assets, and that identifiable intangible assets acquired in business combinations are not value relevant when they are not strategically important.

We also contribute to the literature on the market consequences of, and factors influencing managers' decisions regarding accounting for business combinations. Several studies in this literature have examined how compensation, financial reporting, and tax incentives influence firms' purchase price allocation decisions (Shalev, Zhang, and Zhang 2013; Lynch et al. 2019; Wangerin 2019). Other studies suggest that the accounting model for business combinations contributes to increases in information uncertainty (Erickson et al. 2012; Dickinson et al. 2016). The economic characteristics we examine - wasting, organically replaced, and strategic importance - are prominent factors in investors' assessments of firms' acquisition decisions, but have not been studied in prior research.

Third, prior research has criticized the current accounting model for identifiable intangible assets for not recognizing in the balance sheet all intangible assets, especially internally developed intangibles (Schancht, McEnally, and Palacky 2007; Lev and Gu 2016). Our findings suggest that not all capitalized intangibles provide a relevant and faithful representation of the future cash flows used by investors in security pricing. This provides evidence that capitalization of intangibles may 
not offer the panacea that prior research has suggested. In addition, our findings suggest that standard setters may consider alternative means to augment or replace the capitalization of intangible assets to provide decision-useful information to investors that better meet the objective of financial reporting.

There are two primary limitations to our research. First, we caution that our results do not address the question of whether and how the FASB should revise accounting policy. Policy questions are multifaceted, require welfare analyses, and are beyond the scope of this study (Gonedes and Dopuch 1974). Second, we caution that our design does not support causal evidence regarding how investors use and process financial statement information. Rather, our findings provide inferences about how accounting amounts reflect information in investors' consensus beliefs impounded in market prices (Barth et al. 2001). Despite these limitations, we believe our results provide important insights to standard setters about how investors perceive economic differences among identifiable intangible assets acquired in business combinations.

\section{HYPOTHESIS DEVELOPMENT}

ASC Topic 805 requires recognition of all acquired assets and liabilities assumed in a business combination at acquisition date fair value, with the residual unallocated purchase price recorded as goodwill. According to the measurement guidance in SFAS 157, Fair Value Measurements (FASB 2006; codified and currently active in ASC Topic 820), fair values for identifiable intangible assets are generally level 2 or level 3 estimates because there are rarely identical assets traded in active markets. ${ }^{3}$ Valuation professionals generally recommend using an income approach to value most intangibles, which are based on projected future cash flows, sales, or income,

\footnotetext{
${ }^{3}$ Most fair value estimates for intangible assets use level 3 inputs, but there are certain cases where transactions involving similar (but not identical) assets are observable. In these cases, level 2 inputs are most commonly available for internet domain names, FCC licenses, and carbon emission rights (AICPA 2012).
} 
discounted to present value on the acquisition date (Crane and Dyson 2009; AICPA 2012). Therefore, fair value estimates for each identifiable intangible acquired in a business combination reflect information in management's estimates of the expected future net cash flows the asset will generate.

Prior research shows that, on average, intangibles are positively associated with equity prices (e.g, Barth and Clinch 1998). However, several studies highlight cross-sectional variation in the market pricing of intangibles. Using a sample of large Australian firms, Godfrey and Koh (2001) find that balance sheet intangibles other than capitalized R\&D costs are positively associated with equity prices. Al Jifri and Citron (2009) find that intangible assets recognized under U.K. GAAP are positively associated with equity prices, but only for firms that engage in $R \& D$. Related to the business combinations setting in the U.S., Kimbrough (2007) examines a sample of acquisitions involving technology-related intangibles. This study shows that acquirers' fair value estimates are positively associated with target firm pre-acquisition equity market values. The positive association is stronger when the target firm has greater analyst following and when more intangibles are recognized on the balance sheet prior to the acquisition. Wangerin (2019) finds that in-process $R \& D$ is positively associated with post-acquisition equity prices, on average, but the association between in-process $R \& D$ and equity prices becomes insignificant in acquisitions where the acquiring firm performed less due diligence.

In sum, prior literature has demonstrated variation in value relevance of specific identifiable intangibles related to characteristics of the firm and its information environment. Investors identify important underlying economic characteristics related to all identifiable intangibles that suggest potential differences in the value relevance not studied in prior research, which is the unique contribution of our study. Specifically, some investors assert that acquired 
identifiable intangible assets can be classified as either a wasting intangible or an organically replaced intangible (FRC 2014). Wasting intangible assets have identifiable revenue streams that do not require future investment to maintain or enhance their value, and these assets often have definite lives that are legally or contractually determined.

Investors identify technology- and contract-related intangibles such as patents and wireless spectrum broadcast licenses as common examples of wasting intangibles. In the case of patents acquired in a business combination, the acquiring firm has the exclusive right to use the patented technology over the remaining legal life until the patent expires. For example, sales of a patented product can be made to generate a future revenue stream that can be identified separately from other revenue streams, and there are no expenditures necessary to maintain the value of an existing patent acquired in the business combination. Acquired wireless spectrum licenses allow the acquiring firm rights to broadcast over communications networks (e.g, radio, television, cellular phones). Although revenue models may differ across networks, future revenue streams are identifiable, and no additional expenditures are required to maintain access to the license.

Organically replaced intangibles generate cash flows over an uncertain time period. These assets also arise from the firm's daily operations and require ongoing future investment to maintain or enhance the asset's cash flow generating ability. Organically replaced intangibles often are marketing- or customer-related and are maintained by making continuing marketing or other ongoing expenditures. For example, some investors claim that the value of tradenames and brands depend on future advertising and promotional activities. Organically replaced intangibles such as customer relationships also depend on continuing efforts to generate future sales with the customer. Therefore, it is difficult to identify and disentangle the future revenue stream related to the organically replaced intangible assets acquired in the business combination on the acquisition 
date from the continuing post-acquisition investments made to maintain or enhance the asset over time (e.g., post-acquisition advertising expenditures to promote an acquired brand) (FRC 2014).

Our first set of hypotheses distinguish between wasting and organically replaced intangibles. Fair value estimates reflect information about management's expectations of the discounted future cash flows from both wasting and organically replaced intangible assets acquired in a business combination. Despite the underlying economic differences between wasting and organically replaced intangibles, acquisition date fair value estimates of both wasting and organically replaced intangibles will be positively associated with equity prices if they reflect decision useful information about the amount, timing, and uncertainty of future cash flows. However, we may fail to find a positive association between equity prices and identifiable intangibles if investors do not consider information about acquired identifiable intangibles to be relevant or a faithful representation of the future cash flows to the acquiring firm. Many investors raise concerns that the information reported for organically replaced intangibles is incomplete because future cash inflows depend on uncertain future investments (FRC 2014). The first hypothesis is stated below in alternative form.

H1a: Wasting intangibles are positively associated with post-acquisition equity prices.

H1b: Organically replaced intangibles are positively associated with post-acquisition equity prices.

When an asset exhibits a positive and significant association with equity prices, it is consistent with the asset being a relevant and faithful representation of investors' consensus expectations of the amount, timing, and uncertainty of future cash flows (Barth et al. 2001). However, we also predict that the positive associations between equity prices with wasting and organically replaced intangibles will differ. The summary of investor views above suggests that fair value 
measurements estimate more faithfully represent the future cash flows that arise from wasting than from organically replaced intangible assets. Due to indefinite and uncertain future investment horizons, the distribution of future cash flow realizations for organically replaced intangible assets is less complete and more uncertain at the acquisition date than for wasting intangible assets. Therefore, fair value estimates should better reflect expected future cash flows from a wasting asset that does not require additional expenditures to maintain or enhance and create additional uncertain future value, all else equal. The analytical characterization of accounting information in Lambert, Leuz, and Verrecchia (2007) suggests that the relation between accounting information and equity prices approaches zero as that accounting information and/or the cash flows underlying that information are more uncertain. Therefore, the second hypothesis is as follows (stated in alternative form):

H2: Organically replaced intangibles are less positively associated with post-acquisition equity prices than wasting intangibles.

The third hypothesis examines the association between post-acquisition equity prices and organically replaced intangibles relative to goodwill. The residual unallocated purchase price recorded as goodwill includes unidentifiable assets (i.e., assets that are neither separable, nor legally/contractually determined). Unidentifiable assets comprising goodwill include expected synergies arising from the business combination, the going concern value of the target firm, and assembled workforce (Johnson and Petrone 1998; Henning, Lewis, and Shaw 2000). ${ }^{4}$ Similar to organically replaced intangibles, goodwill has no identifiable cash flow stream and it is difficult

\footnotetext{
${ }^{4}$ Going concern value represents the additional rate of return generated by the target firm's net assets than could be realized if those assets were separately acquired. Goodwill also can reflect overpayment and over-valuation of stockbased consideration, but neither of these goodwill components meet the conceptual definition of an asset (Johnson and Petrone 1998).
} 
to disentangle the acquired goodwill from internally created goodwill generated by continuing investments after the acquisition date.

Investors raising criticisms of accounting for organically replaced intangibles claim that they treat these intangibles like goodwill in their analyses and therefore, call for organically replaced intangibles to be subsumed within the goodwill balance (FRC 2014). Bauman and Shaw (2018) find that customer-related intangibles are positively associated with equity prices, but that this association is significantly less positively associated with equity prices than goodwill. Consistent with the findings in prior research, we expect that goodwill is positively associated with equity prices (Barth and Clinch 1998; Jennings et al. 1996; Henning, Lewis, and Shaw 2000; Bauman and Shaw 2018; Wangerin 2019). However, we expect that the association between goodwill and post-acquisition equity market values will be similar to organically replaced intangibles because goodwill also requires continuing post-acquisition investment and has no identifiable cash flow stream. ${ }^{5}$ The third hypothesis is stated below in null form.

H3: The association between goodwill and post-acquisition equity prices is not significantly different from the association between organically replaced intangibles and post-acquisition equity prices.

Prior to SFAS 141, an economically heterogeneous group of intangibles was included in the goodwill balance (FASB 2001a, para. B149; FASB 2007, para. B158). To disaggregate intangibles with different economic characteristics, ASC 805 requires firms to recognize intangible assets separately from goodwill when they satisfy the identifiability criterion. The identifiability criterion

\footnotetext{
${ }^{5}$ If the information reflected in organically replaced intangibles and goodwill is a reliable and faithful representation of future cash flows, we expect both types of assets will be positively associated with equity prices. However, uncertainty about future cash flows related to organically replaced intangibles and goodwill may drive their associations with post-acquisition equity prices to zero.
} 
is satisfied for intangibles that arise from contractual/legal rights or are separable from the entity, i.e., capable of being sold, licensed, exchanged, rented, or transferred (FASB 2007, para. B160). Investors claim that the identifiability criterion in the current financial reporting model sometimes requires recognition of assets that are not of strategic importance, which is of little informational value (PwC 2007; FRC 2014). The FASB also acknowledged that application of the identifiability criterion would sometimes lead to recognized intangibles that do not meet the conceptual definition of an asset (FASB 2001a, para. B155).

Our final set of hypotheses examine the effects of strategic importance on the relation between identifiable intangibles and equity prices. Investors use disclosures required for business combinations to assess management's performance, and to benchmark future performance against management's initial expectations (FRC 2014). More specifically, some investors noted the importance of understanding "management's rationale for undertaking particular business combination transactions in context of the assets acquired and the benefits arising from the use of those assets" (FRC 2014 pg. 10). Therefore, investors demand information about the underlying economic value-drivers of the acquisition and management's assumptions about how the assets are expected to generate value.

Because fair value estimates reflect management's estimates of future cash flows discounted to present value on the acquisition date, we hypothesize that both (1) the most strategically important intangibles, and (2) other identifiable intangibles are positively associated with postacquisition equity prices. However, the investor arguments above also could motivate the prediction that other intangibles are unrelated to post-acquisition equity prices if they do not reflect information about significant sources of future economic benefit. Given the possible recognition of identifiable intangible assets that are insignificant to future cash flows, we also predict that the 
association between other intangibles and equity prices is less positive than strategically important intangibles. The fourth and fifth hypotheses are stated below in alternative form:

H4a: Strategically important intangibles are positively associated with post-acquisition equity prices.

H4b: Other intangibles are positively associated with post-acquisition equity prices.

H5: Other intangibles are less positively associated with post-acquisition equity prices than strategically important intangibles.

\section{RESEARCH DESIGN}

\section{Price-Level Framework}

Our research design draws on prior value relevance literature that examines the association between equity prices with earnings and book values. This research uses equity prices to capture investors' consensus beliefs about the amount, timing, and uncertainty of future cash flows to the firm. Therefore, equity prices reflect investor expectations about future cash flows discounted to present value (Barth et al. 2001; Barth 2007). Positive associations between equity prices with earnings and book values suggest that these accounting numbers provide information consistent with investors' beliefs about future cash flows to the entity. This interpretation is consistent with an information perspective, which focuses on accounting providing information to financial statement users for making economic decisions related to the reporting entity (Barth 2007).

Under an information perspective, positive and significant associations between assets and equity prices are interpreted as evidence that the asset value is both a (1) relevant, and (2) faithful representation of investors' consensus expectations about the amount, timing, and uncertainty of future cash flows (Barth 2007). When a coefficient fails to exhibit a significant predicted association with equity prices, it is difficult to distinguish empirically whether the insignificant 
association is due to a lack of relevance, faithful representation, or both. Therefore, tests under the information perspective are joint tests of relevance and faithful representation (Barth et al. 2001).

Some studies in the value relevance literature take a measurement perspective, where relevance is generally assumed and hypotheses are tested for particular valuation coefficients. Such tests can be difficult to specify and conduct, often requiring strong assumptions and structure. Tests based on the information perspective are similar to the measurement perspective, but generally involve predictions that the coefficient on the accounting amount differs from zero, whereas the measurement perspective might result in a prediction that the coefficient equals a specific theoretical value (Barth 2007, pg. 92). All studies that take a measurement or information perspective rely on extensive evidence in the accounting and finance literature that equity markets efficiently impound publicly available information in prices. Prior research shows that when potential market inefficiencies exist, any bias to parameter estimates in price-level regressions is not economically significant, therefore those estimates support reliable inferences (Aboody, Hughes, and Liu 2002; Barth 2007).

Prior research also operationalizes the value relevance of book values in alternative ways, including studies that associate recognized asset values with future income (e.g., Aboody and Lev 1998) and operating cash flows (e.g., Deng and Lev 2006). It is important to recognize in our setting that there is significant heterogeneity in the pattern over which future cash flows and earnings arise from different types of intangible assets. For example, Clarke (1976) estimates the benefits to marketing-related intangibles (e.g., tradenames, brands, etc.) are realized between three and 15 months. In contrast, Healy, Myers, and Howe (2002) propose that a commercialized pharmaceutical can generate cash in-flows while under patent for upwards of ten years.

The price-level framework compares two measures that discount future cash flows (i.e., fair values and stock prices), which impound heterogeneity in the timeframe over which cash inflows 
and outflows are expected to arise. Therefore, the price-level framework offers a methodological advantage in our setting over research designs using future earnings or cash flow realizations. Specifically, research designs using ex-post realizations generally require aggregation of those realizations over a constant number of limited years. For example, analysis of one specific type of intangible asset (e.g., patents), would be well-suited to this research design because the benefit period of the asset is defined and can be held constant across observations. In contrast, our empirical analyses include all types of identifiable intangibles, which vary substantially in patterns of future cash in- and outflow realization horizons (i.e., developed technology, contract-related intangibles, customer-related intangibles, trademarks, and in-process R\&D). Therefore, in our setting, it is not possible to specify a consistent aggregation window without including or excluding realizations outside the cash flow realization horizons. Absent a model that explicitly captures heterogeneity in the expected pattern of future cash flows, we believe the price-level framework is well-suited to support reliable inferences in our research setting.

Other studies operationalize value relevance by examining the associations between stock returns with earnings and changes in book values (e.g., Barth and Clinch 1998; McInnis, Yu, and Yust 2018). In contrast to a price-level framework, Aboody et al. (2002) show that inferences in value relevance studies examining stock returns are sensitive to market inefficiencies where information is incorporated into changes in prices with a delay. Therefore, the price-level framework, which compares the level of recognized book values and stock prices, offers more reliable evidence on how different types of acquired identifiable intangible assets relate to investors' expectations. More specifically, we are interested in how acquisition date fair value measurements of acquired identifiable intangibles are reflected in investor equity valuations. We 
therefore choose to rely on the price-level framework because it measures firm value whereas returns-based models measure changes in firm value over time (Barth et al. 2001, pg. 95).

\section{Model specification}

Throughout our tests, we regress acquiring firm stock prices on earnings and book values. We disaggregate book values into acquired identifiable intangibles, goodwill, and all other net assets of the acquiring firm at the end of year $t$. Stock price, Price $_{i, t}$, is defined as acquiring firm stock price (per share). We measure equity prices on the $63^{\text {rd }}$ trading day after the fiscal year-end (i.e., one quarter into a year with 252 trading days) following the acquisition completion date. This allows for investors to obtain and process audited financial statement information about acquired identifiable intangibles corresponding to each acquisition in the sample.

Although the research design is not capable of supporting causal inferences, it is nonetheless important to consider the effects of potentially correlated omitted variables. Our model derives from prior research where firm value is a function of earnings and book values (e.g., Aboody, Barth, and Kasznik 2004). Therefore, the model includes variables that capture earnings, book values, acquired identifiable intangibles, and goodwill. $N I_{i, t}$, is income before extraordinary items and $B V_{i, t}$, is book value of equity less acquired identifiable intangible assets and goodwill for firm $i$ at the end of the acquisition completion year. ${ }^{6}$ All the models include annual and industry-year fixed effects to account for the possible effects of unobserved heterogeneity across industries and over time. We do not have a panel dataset, therefore, we use industry-level, rather than firm, fixed effects. To mitigate the potential for scale-related coefficient bias and heteroskedasticity, we scale all variables by common shares outstanding on the $63^{\text {rd }}$ trading day after the end of fiscal year $t$ (Barth and Clinch 2009). Standard errors are clustered by firm.

\footnotetext{
${ }^{6}$ Detailed definitions for all variables are included in Appendix A.
} 
We test our first set of hypotheses related to wasting and organically replaced identifiable intangible assets by estimating equation (1). Consistent with prior research, we expect that earnings and book values will exhibit positive and significant associations with equity prices. Finding a positive and significant coefficient on intangible assets classified as wasting, Wasting_II $I_{i, t}$, provides support for H1a that wasting intangibles are positively associated with post-acquisition equity prices. Similarly, we expect a positive and significant coefficient on Organic_II, $I_{i, \text { which }}$ would support the prediction in $\mathrm{H} 1 \mathrm{~b}$ that organically replaced intangibles are positively associated with post-acquisition equity prices. $\mathrm{H} 2$ predicts that organically replaced intangibles are less positively associated with equity prices than wasting intangibles. Therefore, we predict that the coefficient on Organic_II $I_{i, t}$ is significantly less than the coefficient on Wasting_II $I_{i, t}\left(a_{3}>a_{4}\right)$. H3 predicts no difference in the association between post-acquisition equity prices with organically replaced intangibles and goodwill. Therefore, we expect that the coefficients on Organic_II $I_{i, t}$ and Goodwill $_{i, t}$ will be equal $\left(a_{4}=a_{5}\right)$.

$$
\begin{aligned}
\text { Price }_{i, t}= & a_{0}+a_{1} B V_{i, t}+a_{2} N I_{i, t}+a_{3} \text { Wasting_II }_{i, t}+a_{4} \text { Organic_II }_{i, t}+a_{5} \text { Goodwill }_{i, t} \\
& + \text { Annual and industry-year fixed effects }+e_{i, t}
\end{aligned}
$$

We rely on investors' characterizations of the distinguishing features of wasting and organically replaced intangibles to define the variables Wasting_II $I_{i, t}$ and Organic_II $I_{i, t}$. The key feature of organically replaced intangibles is the requirement of continuing investments to maintain or enhance the value of the asset (FRC 2014). Therefore, we classify customer-related intangibles, trademarks, tradenames, and brands as organically replaced intangibles, due to their dependence on future expenditures for marketing and promotional activities. We also classify inprocess $\mathrm{R} \& \mathrm{D}$ as an organically replaced intangible asset because ongoing research and development expenditures must be incurred before the asset can generate an identifiable stream of future cash flows. The remaining types of identifiable intangibles in our sample are classified as 
wasting. These intangibles are developed technologies and contract-related intangibles, both of which have identifiable revenue streams that do not require future investment and often have definite useful lives that are legally or contractually determined.

Our second set of hypotheses is tested by estimating equation (2). The model regresses postacquisition stock prices on earnings, book values, and goodwill, partitioning identifiable intangibles based on classifications of strategic importance. According to $\mathrm{H} 4 \mathrm{a}$ and $\mathrm{H} 4 \mathrm{~b}$, we expect that the coefficients on both strategic, MostSI_II $I_{i, t}$, and other identifiable intangibles, Other_II $I_{i, t}$, will be positive and significant. Under $\mathrm{H} 5$, we hypothesize that the coefficient on Other_II $I_{i, t}$ is significantly less than the coefficient on $\operatorname{MostSI}_{-} I I_{i, t}\left(b_{3}>b_{4}\right)$.

$$
\begin{aligned}
\text { Price }_{i, t}= & b_{0}+b_{1} B V_{i, t}+b_{2} N_{i, t}+b_{3} \text { MostSI_III,t }+b_{4} \text { Other_II }_{i, t}+b_{5} \text { Goodwill }_{i, t} \\
& + \text { Annual and industry-year fixed effects }+e_{i, t}
\end{aligned}
$$

To identify strategically important intangibles, we use the percentage that each specific intangible asset acquired is of the total assets acquired to determine whether the asset is a primary source of future economic benefits of the business combination. We operationalize this construct in two alternative ways. First, the variable $M o s t S I I I I_{-} A v g_{i, t}$ represents that the individual intangible asset as a percentage of total assets acquired is greater than the mean individual intangible within the sample as a percentage of total assets acquired. The second strategic importance variable, MostSI_II_IndAvg $g_{i, t}$, represents that the individual intangible asset as a percentage of total assets acquired is greater than the mean individual intangible within the acquiring firm's industry as a percentage of total assets acquired. ${ }^{7}$ The underlying assumption for each variable we use to capture strategic importance is that intangible assets representing key economic value-drivers for the acquisition likely account for a larger portion of total assets acquired. Intangibles not classified as

\footnotetext{
${ }^{7}$ Acquiring firm industry membership is based on the Fama-French 48 industry classifications.
} 
strategically important using the variables MostSI_II_Avg $g_{i, t}$ and MostSI_II_IndAvg $g_{i, t}$ are included in the variables $O t h e r \_I I A v g_{i, t}$ and $O t h e r \_I I \_I n d A v g_{i, t}$, respectively.

To illustrate the construct of strategically important intangible assets, we include an excerpt from the Symantec Corporation 10-K filing for the fiscal year ended March 31, 2017. The excerpt is extracted from the acquisitions footnote disclosure for the $\$ 4.7$ billion purchase of Blue Coat, Inc. Fair value estimates for acquired identifiable intangibles totaled approximately $\$ 1.6$ billion, consisting mostly of customer relationships (\$844 million) and developed technology and patents (\$739 million). Consistent with these large allocations to intangibles, Symantec discussed in a press-release that this deal was driven by Blue Coat's 15,000 corporate clients, representing more than 70 percent of the Fortune Global 500, and its developed technology making it a market leader in web security products. However, to acquire these presumably value-driving assets from Blue Coat, Symantec had to acquire control of Blue Coat, which we posit also included intangible assets insignificant to the value of the deal. Specifically, the purchase price allocation also included $\$ 4$ million to trade names, $\$ 2$ million to production backlog, and $\$ 19$ million to in-process R\&D. Given the allocations to these assets are far smaller than the allocations to customer lists and developed technologies, we expect they are less likely to be of strategic importance to the future cash flows from the acquisition.

\section{Purchase Price Allocation Data}

To provide evidence on our research question, we utilize a proprietary dataset on purchase price allocations to identifiable intangible assets and goodwill. This proprietary dataset is the most comprehensive source of data on purchase price allocations of which we are aware, covering acquisitions made by U.S. public companies. Between 2009-2016, the proprietary dataset provides 
purchase price allocation information for over 3,500 deals aggregating to more than $\$ 3$ trillion in total assets acquired.

Transactions are considered for inclusion in the proprietary dataset if they (1) are in S\&P Capital IQ, (2) closed between 2009 and 2016, (3) involve a U.S. publicly traded bidder, (4) the ownership percentage sought was at least 50\%, and (5) the bidder discloses the purchase price. Transactions from this pool are included in the dataset if the (1) purchase consideration, (2) acquisition date fair values of identifiable intangible assets, and (3) goodwill associated with each deal are disclosed in public filings. We were provided with additional information about the proprietary data for $2013,2014,2015$, and 2016 . In these years, approximately $35 \%, 42 \%, 37 \%$, and $35 \%$ of the initial samples of deals had sufficient disclosure to be included in the dataset, respectively. ${ }^{8}$

The dataset classifies identifiable intangibles into five categories including (1) developed technology, (2) in-process research and development (IPR\&D), (3) trademarks and tradenames, (4) customer-related, (5) other identifiable intangible assets. ${ }^{9}$ Therefore, the dataset both provides us with a sample of deals with sufficiently disaggregated purchase price allocations to study individual types of identifiable intangible assets and separates intangible assets into sufficiently dissimilar categories to facilitate our analysis. We randomly select four years of data between 2010 and 2016 to hand-inspect fifteen deals in each year. For each year, we verify the amounts recorded in every field for (1) the five deals with the largest purchase price, (2) the five deals with the smallest purchase price, and (3) the five deals with the largest amounts recorded as other intangible

\footnotetext{
${ }^{8} \mathrm{We}$ assume these statistics are representative of prior years in the proprietary dataset.

${ }^{9}$ The proprietary dataset also reports goodwill, but does not report disaggregated information on other categories of acquired assets and liabilities.
} 
assets. ${ }^{10}$ By accessing firms' $10-\mathrm{Q}$ and $10-\mathrm{K}$ filings, we were able to confirm the reliability of the proprietary dataset for our analysis, how intangibles are classified into each of the five categories listed above, and did not detect any systematic errors. Finally, we also observed intangibles assets classified by the dataset in the "other" category are generally contract-related intangibles (e.g., FCC licenses, franchise rights, favorable lease contracts, and non-compete agreements).

\section{Sample Selection and Summary Statistics}

Our sample of acquisitions begins in 2009. SFAS 141R (FASB 2007) became effective for fiscal years that begin on or after December 15, 2008. Therefore, deals that closed in 2009 or thereafter are subject to consistent accounting guidance for recognition and measurement of identifiable intangibles acquired in a business combination. SFAS 141R provides more explicit guidance on the definition of a business combination and establishes the identifiability criterion for recognizing intangible assets. SFAS $141 \mathrm{R}$ also changed the reporting for IPR\&D from immediate write-off to recognition as an indefinite-life intangible asset. ${ }^{11}$ It is also worth noting that SFAS 157, Fair Value Measurement, became effective for financial statements with fiscal years beginning after November 15, 2007 (FASB 2006), providing a more consistent measurement framework for determining acquisition date fair values of identifiable intangible assets. The sample

\footnotetext{
${ }^{10}$ ASC 805 allows firms a period of twelve months from the acquisition date to determine the final purchase price allocation and thus, firms release several $10-\mathrm{Q}$ and $10-\mathrm{K}$ filings after deal completion that sometimes contain preliminary purchase price allocations. We found the recorded amounts in the dataset often are taken from preliminary purchase price allocations. To the extent the amounts recorded in the proprietary dataset are positively correlated with purchase price allocation amounts recorded in other $10-\mathrm{Q}$ or $10-\mathrm{K}$ filings, this only reduces the power of our tests.

${ }^{11}$ Under current GAAP, firms capitalize at acquisition date fair-value IPR\&D, and once IPR\&D is complete, reclassify it as definite-lived and account for the balance under an amortization-and-impairment approach. If the IPR\&D is discontinued because the firm no longer expects to realize a future benefit, the firm immediately writes the balance of IPR\&D down to zero. This accounting treatment is effectively an amortization-and-impairment approach with a delayed first amortization charge. SFAS $141 \mathrm{R}$ also changed previous accounting for business combinations requiring transaction costs to be expensed rather than qualifying for inclusion in the purchase consideration, and requires recognition of liabilities for contingent consideration. Both of these changes alter residual allocations of the purchase price to goodwill.
} 
ends with deals completed in 2016, which is the most recent year in which we were able to obtain access to the proprietary dataset.

Between 2009 and 2016, the sample begins with 3,567 distinct acquisitions. We apply several screens to the proprietary dataset necessary to conduct our tests. Table 1 Panel A outlines these screens and reports on the number of observations. The database includes deals with bidders traded on any U.S. exchange (e.g., OTC). However, we require data from CRSP on market observables (i.e., daily stock prices, common shares outstanding), and therefore, remove 457 acquisitions completed by acquiring firms not traded on the NYSE, Nasdaq, or Amex because these are the only exchanges covered by CRSP. To ensure that all acquisitions in the sample are accounted for under U.S. GAAP and subject to the same SEC oversight and enforcement, we drop 127 acquisitions completed by acquirers incorporated outside the U.S. or with ADRs listed on U.S. exchanges. Finally, we lose three additional transactions with missing Compustat/CRSP data required to construct the regression covariates. The remaining sample consists of 2,980 acquisitions, 420 of which are completed by the same acquirer within the same fiscal year as at least one other acquisition. We aggregate these transactions at the firm-year level throughout our analyses, resulting in 2,560 firm-year observations.

--Insert Table 1 about here--

Table 1 Panel B shows summary statistics on the number of deals and average transaction value by acquirer industry. Consistent with historical M\&A market activity and prior research (Carnes, Christensen, and Lamoreaux 2018; Kravet, McVay, and Weber 2018), the sample is most heavily concentrated in the business equipment $(n=1,028)$, financial $(n=438)$, and healthcare sectors $(n=350)$. Across the 12 industries reported in Panel B, the average purchase price exceeds $\$ 500$ million in seven industries, with the largest purchase price in the telecommunications 
industry (mean $=\$ 1.06$ billion). We report summary statistics on the proprietary data at the deal level in Table 1 Panel C. The average purchase price is $\$ 502.23$ million, although the distribution is highly skewed by large acquisitions (median $=\$ 53$ million; $75^{\text {th }}$ percentile $=\$ 229.37$ million). The data show that at the mean (median), identifiable intangible assets are $43.58 \%(37.76 \%)$ of the purchase price, with an interquartile range between $21.54 \%$ and $54.17 \%$. The allocations to goodwill are slightly higher, but comparable, at $52.9 \%$ and $50 \%$ of the purchase price at the mean and median, respectively.

Descriptive statistics for all covariates used in the regression models are reported in Table 2 Panel A. To minimize the influence of extreme observations, all variables are winsorized at the top and bottom $1 \%$ of their distributions. ${ }^{12}$ The descriptive statistics show that the average postacquisition stock price within the sample is $\$ 34.008$ (median=\$24.960) per share. The vast majority of firm-year observations have positive book values and earnings. The mean (median) book value per share is $\$ 9.787$ ( $\$ 7.353)$ and net income per share is $\$ 1.153(\$ 0.801)$.

--Insert Table 2 about here--

Turning to the identifiable intangible assets, we first report descriptive statistics for intangibles classified as wasting (Wasting_II $I_{i, t}$ ). There are 2,130 observations where at least one wasting intangible asset is recognized, with a mean and median value of $\$ 0.510$ and $\$ 0.155$ per share, respectively. Within wasting intangibles, there are 1,247 observations in which developed technology is recognized and 1,406 contract-related intangibles. Table 2 Panel A also shows 2,058 observations with at least one organically replaced intangible (Organic_II $\left.I_{i, t}\right)$ recognized in the

\footnotetext{
${ }^{12} \mathrm{We}$ also examine regression diagnostics in all of our tests for the effects of potentially influential observations on our tests. All of our tests are robust to estimating robust regressions and eliminating observations with absolute studentized residuals $>2.0$ or DFFITS $>$ than $2 *(\mathrm{k} / \mathrm{n})^{1 / 2}$ (Leone, Minutti-Meza, and Wasley 2019; Belsley, Kuh, and Welsch 1980).
} 
purchase price allocation with a mean (median) value of $\$ 1.212(\$ 0.326)$ per share. Within organically replaced intangibles, most correspond to customer-related intangibles $(n=1,776)$ or trademarks and tradenames $(n=1,364)$. In-process $R \& D$ is recognized in 338 observations, primarily concentrated in the business equipment (188 acquisitions, untabulated) and healthcare, medical equipment, and drugs industries (147 acquisitions, untabulated). Mean (median) recognized goodwill is $\$ 2.015$ ( $\$ 0.616$ ) per share, which is comparable to mean (median) total identifiable intangibles of $\$ 1.437$ (\$0.416).

Next, we report descriptive statistics for the intangibles we classify as strategically important. There are 1,827 observations where at least one intangible (when scaled by total assets acquired) is above the sample mean of that ratio (MostSI_II_Avg $g_{i, t}$ ) and 1,852 observations with at least one intangible (when scaled by total assets acquired) is greater than the industry-specific mean of that ratio (MostSI_II_IndAvg $g_{i, t}$ ). Distributions for MostSI_II_Avg $g_{i, t}$ and MostSI_II_IndAvg $g_{i, t}$ are similar with mean (median) values of about $\$ 1.42(\$ 0.45)$ per share. Other_II_Avg $g_{i, t}\left(\right.$ Other_II_IndAvg $\left.g_{i, t}\right)$ measure the sum of all identifiable intangible assets for firm $i$ in year $t$ not included in MostSI_II_Avg $g_{i, t}\left(\right.$ MostSI_II_IndAvg $\left.g_{i, t}\right)$ and classify 2,087 $(2,080)$ identifiable intangible assets as not strategically important. In addition, Other_II_Avg $g_{i, t}$ and Other_II_IndAvg $g_{i, t}$ have similar distributions with means (medians) of roughly $\$ 0.49$ (\$0.14) per share.

Panel B of Table 2 reports the industry mix of strategically important intangibles at a more granular level across developed technology $\left(\right.$ DTech $\left._{i, t}\right)$, contract-related (Contract $\left.t_{i, t}\right)$, customerrelated $\left(C R_{i, t}\right)$, tradenames $\left(\operatorname{Trade}_{i, t}\right)$, and in-process $\mathrm{R} \& \mathrm{D}\left(I P R D_{i, t}\right)$, as well as the overall percentage of intangibles classified as strategically important. Across most industries, roughly $30 \%-40 \%$ of intangibles are classified as strategically important, but there is substantial heterogeneity in the types of intangibles that are most strategically important. For example, 36\% 
of the intangibles in the agriculture industry are classified as strategically important, comprised of customer-related intangibles (18\%), contract-related (9\%), and in-process R\&D (9\%). Developed technology is most strategically important in high-tech industries such as medical equipment, computers, and electronic equipment, whereas contract-related intangibles are strategically important most often in mining and hospitality. Customer-related intangibles appear to be highly strategically important across most industries in the sample, particularly in service industries (e.g., entertainment, healthcare, utilities). In contrast, trademarks and tradenames are classified as strategically important in consumer products industries (e.g., food products, beer and liquor, apparel), while in-process $R \& D$ is highly concentrated in pharmaceuticals.

\section{Pairwise Correlations}

Table 3 presents a correlation matrix for all variables used in our analyses. Consistent with prior research, we find that earnings and book values exhibit positive and significant correlations with equity prices. We also find that Wasting_II $I_{i, t}$,Organic_II $I_{i, t}$, and Goodwill $l_{i, t}$ have positive and significant correlations with Price $_{i, t}$ ( $\mathrm{p}$-value $<0.05$; two-tailed test). The correlations provide some univariate evidence supporting $\mathrm{H} 1 \mathrm{a}$ and $\mathrm{H} 1 \mathrm{~b}$, that wasting intangibles and organically replaced intangibles are positively associated with post-acquisition equity prices. These positive correlations persist after disaggregating wasting and organically replaced intangibles across all five categories of identifiable intangible assets reported in the proprietary dataset, DTech $h_{i, t}$, Contract $_{i, t}, C R_{i, t}$, Trade $_{i, t}$, and IPRD $D_{i, t}$. We also find that Price $_{i, t}$ exhibits positive and significant correlations with MostSI_II_Avg $g_{i, t}$ and MostSI_II_IndAvg $g_{i, t}$ (p-value $<0.05$; two-tailed test), consistent with our prediction that strategically important intangibles are positively associated with equity prices (H4a). Likewise, the correlations between Price $e_{i, t}$ with both Other_II_Avg $g_{i, t}$ and 
Other_II_IndAvg $g_{i, t}$ are positive and significant at the 0.05 level (two-tailed test) consistent with our hypothesis that other intangibles are positively associated with equity prices (H4b).

--Insert Table 3 about here--

\section{RESULTS}

\section{Wasting and Organically Replaced Intangibles}

Table 4 presents the results of our analysis of wasting and organically replaced intangibles.

Across all specifications, the adjusted $R^{2}$ coefficients show that the model has significant explanatory power, explaining between $55 \%$ and $57 \%$ of the variation in post-acquisition equity prices. According to our expectations, the coefficients on $B V_{i, t}$ and $N I_{i, t}$ are positive and significant, consistent with book values and earnings being positively associated with equity prices (p-value $<$ 0.01; one-tailed test). In addition, we also find positive and significant coefficients on Goodwill $l_{i, t}$ ranging between 1.156 in column (1) and 1.390 in column (4) (p-value $<0.01$ across all specifications; one-tailed test). The first column in Table 4 reports the results of a baseline specification where the variable Total_ $I I_{i, t}$ includes the sum of all acquired identifiable intangible assets. The coefficient on Total_II $I_{i, t}$ is 1.773 , and significantly different from zero (p-value $<0.01$; one-tailed test). Consistent with the results of prior research (e.g., Kimbrough 2007; Wangerin 2019), we interpret this finding to suggest that, on average, investors' expect acquired identifiable intangible assets will generate net positive future cash inflows to the entity after the acquisition.

The specification reported in column (2) presents the tests of our first set of hypotheses. We find that the coefficients on Wasting_II $I_{i, t}$ and Organic_II $I_{i, t}$ are positive and significant ( $t$-statistics $=4.04$ and 3.69, respectively). These results provide support for H1a and H1b that both wasting and organically replaced intangible assets are positively associated with post-acquisition equity 
prices (p-value $<0.01$; one-tailed). We also find that the coefficient on Wasting_II $I_{i, t}(2.989)$ is significantly greater than the coefficient on Organic_II $I_{i, t}(1.457)($ F-statistic $=3.78 ;$ p-value $<$ 0.05). This result provides support for $\mathrm{H} 2$, the positive association with post-acquisition equity prices is significantly less positive for organically replaced intangibles than wasting intangibles.

The third and fourth specifications reported in Table 4 show the results of sensitivity tests where we exclude acquisitions from the sample involving acquired in-process R\&D or other indefinite-lived intangibles. Due to ongoing continuing investments, we classify in-process R\&D as an organically replaced intangible. However, we recognize that once R\&D activities are completed, the in-process R\&D intangible is reclassified to developed technology or written off. Thus, in-process R\&D is not subject to the same kinds of continuing investments as other organically replaced intangibles (e.g., brands, tradenames, customer lists). After eliminating 338 observations involving in-process $\mathrm{R} \& \mathrm{D}$, we re-estimate equation (1) and find that our results hold. Specifically, we continue to find that the coefficients on Wasting_II $I_{i, t}(2.586)$ and Organic_II $I_{i, t}$ (0.766) are positive and significant ( $p$-value $<0.01$; one-tailed test). We also find that the coefficient on Wasting_II $I_{i, t}$ is significantly greater than the coefficient on Organic_II $I_{i, t}$ (p-value $<$ 0.05 ; one-tailed test). We conclude that our results are robust to the design choice to classify acquired in-process $R \& D$ as an organically replaced intangible asset.

The fourth specification eliminates 421 firm-year observations from the sample where the acquiring firm recognizes an indefinite-lived intangible other than IPR\&D. The purpose of this sensitivity test is to address whether compensation or financial reporting incentives provide alternative explanations that might explain the difference in the coefficients on Wasting_II $I_{i, t}$ and Organic_II $I_{i, t}$ Prior research demonstrates that managers with strong earnings-based compensation or financial reporting incentives are more likely to allocate larger portions of the purchase price to 
goodwill and indefinite-lived intangibles to reduce the effects of post-acquisition amortization (e.g., Shalev et al. 2013; Lynch et al. 2019). By eliminating transactions involving indefinite-lived intangibles other than goodwill, we can better attribute differences in the association between equity prices with wasting and organically replaced intangibles to their underlying economic characteristics. Within this subsample, we continue to find that the coefficients on Wasting_II $I_{i, t}$ and Organic_II $I_{i, t}$ are positive and significant at the 0.01 level (one-tailed test). We also continue to find that the coefficient on Organic_II $I_{i, t}$ is significantly less than the coefficient on Wasting_II $I_{i, t}$ (p-value $<0.01$; one-tailed test), providing additional support for $\mathrm{H} 2$.

Table 4 also presents tests of $\mathrm{H} 3$, which predicts that the coefficient on Organic_II $I_{i, t}$ is equal to the coefficient on Goodwill $i$, . Across all three specifications that disaggregate Organic_II $I_{i, t}$ from Total_II $I_{i, t}$ (columns 2-4), F-tests show that there are no statistically significant differences between the coefficients on Organic_II $I_{i, t}$ and Goodwill $l_{i, t}$. The two-tailed p-values from F-tests where the null hypothesis is the coefficient on Organic_II $I_{i, t}$ is equal to the coefficient on Goodwill $l_{i, t}$ range between 0.339 and 0.954 . It is important to note again that the sensitivity analyses in columns (3) and (4) remove IPR\&D and other indefinite-lived intangibles from Organic $I I_{i, t}$. Therefore, these sensitivity analyses help to further rule out the possibility that the unique economic characteristics of IPR\&D or purchase price allocation incentives drive the results for $\mathrm{H} 2$ and $\mathrm{H} 3 .{ }^{13}$

Overall, the results of our tests are consistent with wasting and organically replaced intangibles providing a relevant and faithful representation of investors' consensus beliefs about the amount, timing, and uncertainty of expected future cash flows. The findings also are consistent with investors' claims that the acquisition date fair values of wasting intangible assets are more decision

\footnotetext{
${ }^{13}$ In all untabulated robustness tests, all results continue to hold when eliminating 539 firm-year observations in which the firm records asset write-downs or goodwill impairments. These results help to rule out the potentially confounding effects of acquisition-year impairments of identifiable intangibles and goodwill.
} 
useful than organically replaced intangibles due to the more complete and therefore less uncertain nature of expected future cash flows from wasting intangible assets on the acquisition date. In addition, our findings are consistent with investors' claims that information about the value of organically replaced intangible assets and goodwill are reflected similarly in equity prices because both types of assets require continued future investment to maintain or enhance their value.

--Insert Table 4 about here--

\section{Strategically Important Intangibles}

Table 5 reports the results of our second set of hypotheses related to strategic importance. Similar to our previous analysis, all specifications exhibit significant explanatory power for postacquisition equity prices with adjusted $R^{2}$ coefficients of 0.573 or better. We also continue to find positive and significant coefficients on $B V_{i, t}, N I_{i, t}$, and Goodwill $l_{i, t}$. The first specification in Table 5 reports the results of our tests when we use the variable MostSI_II_Avg $g_{i, t}$ as the proxy for strategically important intangible assets, which is the sum of all recognized intangible assets in a given firm-year whose values over total assets acquired is above the sample mean (industryspecific mean) of that ratio. The second specification uses MostSI_II_IndAvg $g_{i, t}$ as the proxy for strategically important intangibles.

We find positive and significant coefficients on each strategic importance measure at the 0.01 level (one-tailed test) across all columns. These results are consistent with the prediction in H4a that strategically important intangible assets are positively associated with post-acquisition equity prices. The coefficients on Other_II_Avg $g_{i, t}$ and Other_II_IndAvg $g_{i, t}$ are not significantly different from zero in columns (1) and (2). Turning to H5, we find support for the prediction that the positive association between equity prices and strategically important intangibles is more positive than non- 
strategically important intangibles. Specifically, we find that the coefficient on MostSI_II_Avg $g_{i, t}$ (1.854) is significantly greater than the coefficient on Other_II_Avg $g_{i, t}(0.313)$ in column (1) (Fstatistic $=2.59 ; \mathrm{p}$-value $<0.10$, one-tailed test). Similarly, the coefficient in column (2) on MostSI_II_IndAvg $g_{i, t}(1.822)$ is significantly greater than the coefficient on Other_II_IndAvg $g_{i, t}$ $(0.507)($ F-statistic $=2.06 ;$ p-value $<0.10$, one-tailed test $){ }^{14}$

Taken together, the findings in Table 5 are consistent with investors' assertions that they find financial reporting information useful when related to important strategic factors that support the primary value-drivers of the transaction. The results also suggest that when intangibles are recognized that are not strategically important, they are unrelated to investors' expectations of future cash flows. Although our research design cannot distinguish between relevance and faithful representation, failing to reject the null hypothesis for $\mathrm{H} 4 \mathrm{~b}$ is consistent with investors' claims that not all acquired intangible assets are relevant to their assessments of firm value (PwC 2007).

\section{--Insert Table 5 about here-}

\section{Cross-Sectional Analysis}

In our final set of analyses, we conduct cross-sectional tests examining the associations between equity prices with wasting and organically replaced intangibles, conditional on strategic importance. In doing so, we are able to gain deeper insights about how different underlying economic characteristics of identifiable intangible assets are reflected in investors' consensus

\footnotetext{
${ }^{14} \mathrm{We}$ also considered classifying the largest identifiable intangible asset in each acquisition as an alternative proxy for strategic importance. This variable is positively associated with equity prices ( $\mathrm{p}$-value $<0.01$; one-tailed test), but not significantly different from other intangibles that were not the largest identifiable intangible acquired. We believe that failing to find a significant difference between the coefficients on these variables is likely the result of noise in this particular classification methodology. Specifically, this alternative classification assumes there is exactly one strategically important intangible in each acquisition, whereas MostSI_II_Avg $g_{i, t}$ and MostSI_II_IndAvg $g_{i, t}$ relax that assumption and thus allow for the possibility that multiple or zero strategically important intangibles are acquired in any given acquisition.
} 
beliefs about the expected future cash flows from these assets. Table 6 reports the results of these cross-sectional tests. We examine both classifications of strategic importance (MostSI_II_Avg $g_{i, t}$ and MostSI_II_IndAvg $g_{i, t}$ in columns 1 and 2, respectively). Consistent with our previous results, we find that book values, income, and goodwill exhibit positive and significant associations with equity prices ( $p$-value $<0.01$; one-tailed test).

Several consistent patterns emerge across both wasting and organically replaced intangibles, highlighting the impact of strategic importance and information reflected in investor expectations about acquired identifiable intangibles. Across all three classifications for strategic importance, we find that the coefficients on MostSI\&Wasting ${ }_{i, t}$ and MostSI\&Organici, $i$ are positive and significant at the 0.01 level (one-tailed test). However, the coefficients on MostSI\&Wasting ${ }_{i, t}$ are significantly greater than the coefficients on MostSI\&Organici, at the 0.01 level across all specifications. ${ }^{15}$ These findings suggest that for strategically important assets, both wasting and organically replaced intangibles are a relevant and faithful representation of information reflected in investors' beliefs about expected future cash flows to acquiring firms. Nevertheless, the results also provide further support for our earlier findings that information about wasting intangibles is more decision useful to investors than organically replaced intangibles, even when organically replaced intangibles are primary value-drivers of the acquisition.

--Insert Table 6 about here--

We find no relation between equity prices and identifiable intangibles that are not strategically important. In other words, neither wasting nor organically replaced intangibles are reflected in investors' consensus beliefs about future cash flows when the asset is not strategically important.

\footnotetext{
${ }^{15}$ Consistent with our main analysis, we find that all coefficients on MostSI\&Organic $c_{i, t}$ are not significantly different than the coefficients on Goodwill $l_{, t}$. These results provide additional support for H3.
} 
These findings further highlight the impact of strategic importance in investor expectations about acquired intangible assets, which we interpret to support the overall inference that information about identifiable intangibles is value-relevant only when the assets are a primary source of future economic benefit.

\section{CONCLUSION}

This study investigates whether acquisition date fair value measurements of identifiable intangible assets acquired in business combinations are relevant and faithful representations of investors' expectations about the amount, timing, and uncertainty of future cash flows. The importance of this research question is underscored by the increasing economic significance of intangible assets (FASB 2001a, para. B148; FASB 2007, para. B157) and two potential issues that investors have identified with accounting prescribed by SFAS 141R (FASB 2007) and ASC 805. First, SFAS 141R requires recognition of certain intangible assets that require additional future investment to maintain or enhance their value. As a result, the acquisition date fair value for these assets reflects a less complete and more uncertain measure of expected future cash flow realizations. Investors refer to these intangible assets as organically replaced and indicate a preference that these assets be subsumed in goodwill (FRC 2014). Second, ASC 805 introduces a new separability criterion for recognizing intangible assets which is inconsistent with Conceptual Framework asset definition (FASB 1985; FASB 2001a, para. B155). This difference results in recognition of more identifiable intangible assets, some of which may not be of strategic importance. Investors find non-strategic identifiable intangible assets less relevant to their investment decisions (PwC 2007, FRC 2014).

We examine the associations between post-acquisition equity prices and acquired identifiable intangible assets according to the characteristics of wasting, organically replaced, and strategic 
importance. The analyses show that both wasting and organically replaced intangibles are positively associated with post-acquisition equity prices. However, the positive association between equity market values and organically replaced intangibles is less positive than wasting intangibles. This analysis also shows that organically replaced intangibles and goodwill exhibit similar associations with equity prices. We find a significant positive association between strategically important intangibles and post-acquisition equity prices, but no association for other intangibles. Within the cross-section of strategically important identifiable intangible assets, we find that the positive association between equity market values and organically replaced intangibles is less positive than wasting intangible assets.

The central factor that investors claim distinguishes wasting and organically replaced intangible assets is a need for future ongoing investment over an indefinite and uncertain horizon. Information in fair value estimates of organically replaced intangibles is less complete than wasting intangibles due to uncertainty in the amounts and timing of future investments to maintain or enhance their value. Our findings are consistent with the characterization of accounting information in Lambert et al. (2007) suggesting that the relation between book values and equity prices approaches zero when the accounting information is more uncertain.

Our findings contribute to the literature examining the value relevance of intangible assets. Most prior studies in this line of research examine either intangible assets at an aggregated level or specific types of intangibles (e.g., customer-related, technology-related intangibles), and how characteristics of the firm and its information environment relate to value relevance. Our study offers new evidence that advances the literature by examining how differences in the economic characteristics of identifiable intangible assets - wasting, organically replaced, and strategic importance - explain cross-sectional variation in value relevance. Our research also contributes to 
the literature suggesting that capitalizing intangibles provides a relevant and faithful representation of the future cash flows used by investors in security pricing. The findings from our study suggest that capitalization of intangible assets at fair value provides decision-useful information to investors, but that information is limited to strategically important intangible assets.

Our findings also contribute to the debate over whether the FASB should alter the financial reporting requirements for intangible assets, perhaps in a way that permits balance sheet recognition of internally developed intangibles (Schancht, McEnally, and Palacky 2007; Lev and $\mathrm{Gu}$ 2016). Our findings illustrate that investors may only find fair value information on intangibles decision useful when those assets are a primary source of future cash flows for an entity. In addition, our analyses suggest that investors perceive significant economic differences between certain types of intangibles that may provide a basis for different reporting requirements between wasting and organically replaced intangibles.

We emphasize that there are two primary limitations to our research. First, we cannot make definitive policy recommendations based on our findings. We believe evidence on how differences in value relevance comport with investor claims is a potentially useful input to standard setters. However, making specific policy recommendations is beyond the scope of this study because policy questions are multifaced requiring welfare analyses (Gonedes and Dopuch 1974). Second, our research design does not facilitate causal inferences about how investors use and process financial statement information. Even if investors do not use the fair value information in this study in any way, our findings provide inferences about how accounting amounts are reflected in investors' consensus beliefs about future cash flows to the entity (Barth et al. 2001). Therefore, we believe our results support the inference that investors perceive significant differences in the 
economic characteristics of certain types of intangibles, which is the primary contribution of this study. 


\section{REFERENCES}

Aboody, D., M. E. Barth, and R. Kasznik. 2004. SFAS no. 123 stock-based compensation expense and equity market values. The Accounting Review 79 (2): 251-275.

Aboody, D., J. Hughes, and J. Liu. 2002. Measuring value relevance in a (possibly) inefficient market. Journal of Accounting Research 40 (4): 965-986.

Aboody, D., and B. Lev. 1998. The value relevance of intangibles: The case of software capitalization. Journal of Accounting Research 36 (Supplement): 161-191.

Al Jifri, K., and D. Citron. 2009. The value-relevance of financial statement recognition versus note disclosure: Evidence from goodwill accounting. European Accounting Review 18 (1): 123-140.

American Institute of Certified Public Accountants (AICPA). 2012. CGMA Tools: Three Approaches to Valuing Intangible Assets. New York, NY: AICPA. Available at: https://www.cgma.org/content/dam/cgma/resources/tools/downloadabledocuments /valuing-intangible-assets.pdf

Barth, M. E. 2007. Research, standard setting, and global financial reporting. Foundations and Trends in Accounting 1 (2): 71-165.

Barth, M. E., W. H. Beaver, and W. R. Landsman. 2001. The relevance of the value relevance literature for financial accounting standard setting: Another view. Journal of Accounting and Economics 31 (1): 77-104.

Barth, M. E., and G. Clinch. 1998. Revaluated financial, tangible, and intangible assets: Associations with share prices and non-market-based value estimates. Journal of Accounting Research 36 (Supplement): 199-233.

Barth, M. E., and G. Clinch. 2009. Scale effects in capital markets-based accounting research. Journal of Business Finance and Accounting 36 (3) \& (4): 253-288.

Bauman, M. P., and K. W. Shaw. 2018. Value relevance of customer-related intangible assets. Research in Accounting Regulation 30 (2): 95-102.

Belsley, D., E. Kuh, and R. Welsch. 1980. Regression diagnostics: Identifying influential data and sources of collinearity. New York, NY: John Wiley.

Carnes, R. R., D. M. Christensen, and P. T. Lamoreaux. 2018. Investor demand for internal control audits of large U.S. companies: Evidence from a regulatory exemption for M\&A transactions. The Accounting Review 94 (1): 71-99.

Clarke, D. G. 1976. Econometric measurement of the duration of advertising effect on sales. Journal of Marketing Research 13 (4): 345-357.

Crane, M., and R. A. Dyson. 2009. Risks in applying the new business combination guidance to intangible assets. The CPA Journal 79 (1): 50-58.

Deng, Z., and B. Lev. 2006. In-process R\&D: To capitalize or expense? Journal of Engineering and Technology Management 23 (1): 18-32. 
Dickinson, V., D. D. Wangerin, and J. J. Wild. 2016. Accounting rules and post-acquisition profitability in business combinations. Accounting Horizons 30 (4): 427-447.

Erickson, M., S.-W. Wang, and X. F. Zhang. 2012. The change in information uncertainty and acquirer wealth losses. Review of Accounting Studies 17 (4): 913-943.

Financial Accounting Standards Board (FASB). 1985. Elements of Financial Statements: A Replacement of FASB Concepts Statement No. 3 (Incorporating an Amendment of FASB Concepts Statement No. 2). Statement of Financial Accounting Concepts No. 6: As amended. Norwalk, Connecticut.

Financial Accounting Standards Board (FASB). 2001a. Business Combinations. Statement of Financial Accounting Standards No. 141: As amended. Norwalk, Connecticut.

Financial Accounting Standards Board (FASB). 2001b. Goodwill and Other Intangible Assets. Statement of Financial Accounting Standards No. 142: As amended. Norwalk, Connecticut.

Financial Accounting Standards Board (FASB). 2006. Fair Value Measurements. Statement of Financial Accounting Standards No. 157: As amended. Norwalk, Connecticut.

Financial Accounting Standards Board (FASB). 2007. Business Combinations. Statement of Financial Accounting Standards No. 141 (revised 2007): As amended. Norwalk, Connecticut.

Financial Reporting Council (FRC). 2014. FRC ARP Staff Research Report: Investor Views on Intangible Assets and their Amortisation. Available at: https://www.frc.org.uk /getattachment/ca85acd9-4559-406b-ae96-5a7779772c6b /ResearchProjectonintangibleassetsMarch2014.pdf (last accessed April 4, 2019).

Godfrey, J., and P.-S. Koh. 2001. The relevance to firm valuation of capitalising intangible assets in total and by category. Australian Accounting Review 11 (2): 39-48.

Gonedes, N. J., and N. Dopuch. 1974.Capital market equilibrium, information production, and selecting accounting techniques: Theoretical framework and review of empirical work. Journal of Accounting Research 12: 48-129.

Healy, P. M., S. C. Myers, and C. D. Howe. 2002. R\&D accounting and the tradeoff between relevance and objectivity. Journal of Accounting Research 40 (3): 677-710.

Henning, S. L., B. L. Lewis, and W. H. Shaw. 2000. Valuation of the components of purchased goodwill. Journal of Accounting Research 38 (2): 375-386.

Johnson, L. T., and K. R. Petrone. 1998. Is goodwill an asset? Accounting Horizons 12 (3): 293303.

Jennings, R., J. Robinson, R. B. Thompson II, and L. Duvall. 1996. The relation between accounting goodwill numbers and equity values. Journal of Business Finance \& Accounting 23 (4): 513-533.

Kimbrough, M. D. 2007. The influences of financial statement recognition and analyst coverage on the market's valuation of R\&D capital. The Accounting Review 82 (5): 1195-1225. 
Kravet, T. D., S. E. McVay, and D. P. Weber. 2018. Costs and benefits of internal control audits: Evidence from M\&A transactions. Review of Accounting Studies 23 (4): 1389-1423.

Lambert, R., C. Leuz, and R. E. Verrecchia. 2007. Accounting information, disclosure, and the cost of capital. Journal of Accounting Research 45 (2): 385-420.

Leone, A. J., M. Minutti-Meza, and C. E. Wasley. 2019. Influential observations and inference in accounting research. The Accounting Review (forthcoming).

Lev, B., and F. Gu. 2016. The End of Accounting and the Path Forward for Investors and Managers. Hoboken, NJ: John Wiley \& Sons, Inc.

Lynch, D., M. Romney, B. Stomberg, and D. Wangerin. 2019. Tradeoffs between tax and financial reporting benefits: Evidence from purchase price allocations in taxable acquisitions. Contemporary Accounting Research (forthcoming).

McInnis, J. M., and B. Monsen. 2019. The Operating Returns to Acquired Intangible Assets. Working paper, The University of Texas at Austin and The Ohio State University. Available at: https://papers.ssrn.com/sol3/papers.cfm?abstract id=3279123 (last accessed April 30, 2019).

McInnis, J. M., Y. Yu, and C. G. Yust. 2018. Does fair value accounting provide more useful financial statements than current GAAP for banks? The Accounting Review 93 (6): 257279.

PricewaterhouseCoopers (PwC). 2007. Measuring Assets and Liabilities: Investment Professionals'Views. Available at: https:/www.pwc.com/gx/en/ifrs-reporting/pdf /measuringassetssurvey.pdf (last accessed April 4, 2019).

Schancht, K., R. McEnally, and G. Palacky. 2007. A Comprehensive Business Reporting Model: Financial Reporting for Investors. (July 2007). CFA Institute Centre for Financial Market Integrity. Available at: https://www.cfainstitute.org/en/advocacy/policy-positions /a-comprehensive-business-reporting-model (last accessed July 23, 2019).

Shalev, R., I. X. Zhang, and Y. Zhang. 2013. CEO compensation and fair value accounting: Evidence from purchase price allocation. Journal of Accounting Research 51 (4): 819854.

Wangerin, D. 2019. M\&A due diligence, post-acquisition performance, and financial reporting for business combinations. Contemporary Accounting Research (forthcoming).

Wyatt, A. 2008. What financial and non-financial information on intangibles is value-relevant? A review of the evidence. Accounting and Business Research 38 (3): 217-256. 


\section{Appendix A: Variable definitions}

\begin{tabular}{|c|c|c|}
\hline \multicolumn{3}{|c|}{ Dependent variable } \\
\hline Variable name & Description & Data source \\
\hline Price $_{i, t}$ & $\begin{array}{l}\text { Acquiring firm stock price (per share), measured on the } 63^{\text {rd }} \\
\text { trading day after the end of fiscal year } t \text { (i.e., one quarter } \\
\text { into a year with } 252 \text { trading days). }\end{array}$ & $\begin{array}{l}\text { CRSP Daily Returns } \\
\text { File }\end{array}$ \\
\hline \multicolumn{3}{|c|}{ Independent variables used in wasting versus organically replaced analyses } \\
\hline Variable name & Description & Data source \\
\hline Total_II $I_{i, t}$ & $\begin{array}{l}\text { The magnitude (in dollars) of all recognized identifiable } \\
\text { intangible assets reported in the proprietary dataset for firm } \\
i \text { in fiscal year } t \text {. We scale this variable by common shares } \\
\text { outstanding on the } 63^{\text {rd }} \text { trading day after the end of fiscal } \\
\text { year } t \text { (in CRSP). }\end{array}$ & $\begin{array}{l}\text { CRSP Daily Returns } \\
\text { File and The } \\
\text { Proprietary Dataset }\end{array}$ \\
\hline Wasting_II $I_{i, t}$ & $\begin{array}{l}\text { All recognized identifiable intangible assets reported in the } \\
\text { proprietary dataset for firm } i \text { in fiscal year } t \text { that we classify } \\
\text { broadly as wasting. We construct this variable as the sum of } \\
\text { DTech }_{i, t} \text { and } \text { Contract }_{i, t} \text {. }\end{array}$ & $\begin{array}{l}\text { CRSP Daily Returns } \\
\text { File and The } \\
\text { Proprietary Dataset }\end{array}$ \\
\hline DTech $_{i, t}$ & $\begin{array}{l}\text { The magnitude (in dollars) of all recognized developed } \\
\text { technology reported in the proprietary dataset for firm } i \text { in } \\
\text { fiscal year } t \text {. We scale this variable by common shares } \\
\text { outstanding on the } 63^{\text {rd }} \text { trading day after the end of fiscal } \\
\text { year } t \text { (in CRSP). }\end{array}$ & $\begin{array}{l}\text { CRSP Daily Returns } \\
\text { File and The } \\
\text { Proprietary Dataset }\end{array}$ \\
\hline Contract $_{i, t}$ & $\begin{array}{l}\text { The magnitude (in dollars) of all recognized other } \\
\text { identifiable intangible assets reported in the proprietary } \\
\text { dataset for firm } i \text { in fiscal year } t \text {. We observed in a small } \\
\text { sample that the overwhelming majority of identifiable } \\
\text { intangible assets recorded in this category are contractual in } \\
\text { nature. We scale this variable by common shares } \\
\text { outstanding on the } 63^{\text {rd }} \text { trading day after the end of fiscal } \\
\text { year } t \text { (in CRSP). }\end{array}$ & $\begin{array}{l}\text { CRSP Daily Returns } \\
\text { File and The } \\
\text { Proprietary Dataset }\end{array}$ \\
\hline Organic_II $I_{i, t}$ & $\begin{array}{l}\text { All recognized identifiable intangible assets reported in the } \\
\text { proprietary dataset for firm } i \text { in fiscal year } t \text { that we classify } \\
\text { broadly as organically replaced. We construct this variable } \\
\text { as the sum of } C R_{i, t}, \text { Trade }_{i, t} \text {, and } I P R D_{i, t} .\end{array}$ & $\begin{array}{l}\text { CRSP Daily Returns } \\
\text { File and The } \\
\text { Proprietary Dataset }\end{array}$ \\
\hline$C R_{i, t}$ & $\begin{array}{l}\text { The magnitude (in dollars) of all recognized customer- } \\
\text { related identifiable intangible assets reported in the } \\
\text { proprietary dataset for firm } i \text { in fiscal year } t \text {. We scale this } \\
\text { variable by common shares outstanding on the } 63^{\text {rd }} \text { trading } \\
\text { day after the end of fiscal year } t \text { (in CRSP). }\end{array}$ & $\begin{array}{l}\text { CRSP Daily Returns } \\
\text { File and The } \\
\text { Proprietary Dataset }\end{array}$ \\
\hline
\end{tabular}




\section{Appendix A (continued)}

Independent variables used in wasting versus organically replaced analyses (continued)

\begin{tabular}{ll} 
Variable name & Description \\
\cline { 2 - 2 } Trade $_{i, t}$ & $\begin{array}{l}\text { The magnitude (in dollars) of all recognized trademarks and } \\
\text { tradenames reported in the proprietary dataset for firm } i \text { in } \\
\text { fiscal year } t \text {. We scale this variable by common shares }\end{array}$ \\
& outstanding on the $63^{\text {rd }}$ trading day after the end of fiscal \\
& year $t$ (in CRSP). \\
& The magnitude (in dollars) of all recognized in-process \\
& research and development reported in the proprietary \\
& dataset for firm $i$ in fiscal year $t$. We scale this variable by \\
& common shares outstanding on the $63^{\text {rd }}$ trading day after the \\
& end of fiscal year $t$ (in CRSP).
\end{tabular}

Data source

CRSP Daily Returns

File and The

Proprietary Dataset

CRSP Daily Returns

File and The

Proprietary Dataset

Independent variables used in strategic importance analyses

\begin{tabular}{|c|c|}
\hline Variable name & Description \\
\hline MostSI_II_Avg $g_{i, t}$ & $\begin{array}{l}\text { The magnitude (in dollars) of all recognized identifiable } \\
\text { intangible assets reported in the proprietary dataset for firm } \\
i \text { in fiscal year } t \text { classified as the most strategically } \\
\text { important. To classify intangible assets as most strategically } \\
\text { important, this variable relies on the distribution of in- } \\
\text { sample identifiable intangible assets acquired. To generate } \\
\text { this distribution, we first pool all identifiable intangible } \\
\text { assets across the five classes in the proprietary dataset (e.g., } \\
\text { customer-related) in every deal in our sample ( } 6,976 \text { assets } \\
\text { in total). We scale the magnitude of these assets by total } \\
\text { assets for the deal in which they were acquired. Assets } \\
\text { whose magnitude scaled by total assets acquired are greater } \\
\text { than the mean across all in-sample assets are classified as } \\
\text { most strategically important and included in } \\
\text { MostSI_II } A v g_{i, t} \text {. We scale this variable by common shares } \\
\text { outstanding on the } 63^{\text {rd }} \text { trading day after the end of fiscal } \\
\text { year } t \text { (in CRSP). }\end{array}$ \\
\hline MostSI_II_IndAvg $g_{i, t}$ & $\begin{array}{l}\text { This variable is similar in construction to MostSI_II_Avg } g_{i, t} \text {. } \\
\text { However, the distribution of assets are computed within } \\
\text { each Fama-French } 48 \text { industry classification. Therefore, } \\
\text { assets whose magnitude scaled by total assets acquired are } \\
\text { greater than the mean across all in-sample assets within the } \\
\text { same Fama-French } 48 \text { classification are classified as most } \\
\text { strategically important and included in MostSIII_IndAvg } g_{i, t} \text {. } \\
\text { This variable is set equal to missing if there are less than ten } \\
\text { assets acquired in a Fama-French } 48 \text { industry classification. } \\
\text { We scale this variable by common shares outstanding on } \\
\text { the } 63^{\text {rd }} \text { trading day after the end of fiscal year } t \text { (in CRSP). }\end{array}$ \\
\hline $\begin{array}{l}\text { Other_II_Avg } g_{i, t} \\
\left(\text { Other_II_IndAvg } g_{i, t}\right)\end{array}$ & $\begin{array}{l}\text { The sum of all identifiable intangible assets not included in } \\
\text { MostSI_II_Avg } g_{i, t}\left(\text { MostSI_II_IndAvg } g_{i, t}\right) \text {. }\end{array}$ \\
\hline
\end{tabular}

Data source

CRSP Daily Returns

File and The

Proprietary Dataset

CRSP Daily Returns

File and The

Proprietary Dataset

CRSP Daily Returns

File and The

Proprietary Dataset

Continued next page 


\section{Appendix A (continued)}

\begin{tabular}{|c|c|c|}
\hline \multicolumn{3}{|c|}{ Control variables } \\
\hline Variable name & Description & Data source \\
\hline$B V_{i, t}$ & $\begin{array}{l}\text { Book value of equity (CEQ) less acquired identifiable } \\
\text { intangible assets and goodwill reported in the proprietary } \\
\text { dataset for firm } i \text { measured at the end of fiscal year } t \text {. We } \\
\text { scale this variable by common shares outstanding on the } \\
63^{\text {rd }} \text { trading day after the end of fiscal year } t \text { (in CRSP). }\end{array}$ & $\begin{array}{l}\text { Compustat } \\
\text { Fundamentals Annual } \\
\text { File, CRSP Daily } \\
\text { Returns File, and The } \\
\text { Proprietary Dataset }\end{array}$ \\
\hline$N I_{i, t}$ & $\begin{array}{l}\text { Net income before extraordinary items (IB) for firm } i \\
\text { measured at the end of fiscal year } t \text { scaled by common } \\
\text { shares outstanding on the } 63^{\text {rd }} \text { trading day after the end of } \\
\text { fiscal year } t \text { (in CRSP). }\end{array}$ & $\begin{array}{l}\text { Compustat } \\
\text { Fundamentals Annual } \\
\text { File and CRSP Daily } \\
\text { Returns File }\end{array}$ \\
\hline$G W_{i, t}$ & $\begin{array}{l}\text { The magnitude of recognized goodwill reported in the } \\
\text { proprietary dataset for firm } i \text { in fiscal year } t \text {. We scale this } \\
\text { variable by common shares outstanding on the } 63^{\text {rd }} \text { trading } \\
\text { day after the end of fiscal year } t \text { (in CRSP). }\end{array}$ & $\begin{array}{l}\text { CRSP Daily Returns } \\
\text { File and The } \\
\text { Proprietary Dataset }\end{array}$ \\
\hline
\end{tabular}




\section{Appendix B: Excerpt from Symantec Corporation 10-K filing for fiscal $2017^{16}$}

\section{Blue Coat acquisition}

On August 1, 2016, we acquired all of the outstanding common stock of Blue Coat, a provider of advanced web security solutions for global enterprises and governments. The addition of Blue Coat's suite of network and cloud security products to our innovative Enterprise Security product portfolio has enhanced our threat protection and information protection products while providing us with complementary products, such as advanced web and cloud security solutions, that address the network and cloud security needs of enterprises. This augmentation of our product portfolio, together with the integration of Blue Coat's large threat database with our global civilian cyber intelligence threat network, allows us to provide an integrated cyber defense platform, addressing both endpoint and network security, and offer differentiated security solutions. It also positions us well to introduce new cybersecurity solutions that address the ever-evolving threat landscape, the changes introduced by the shift to mobile and cloud along with the adoption of Internet of Things (IoT) devices. Our enhanced portfolio also positions us well to address the challenges created by regulatory and privacy concerns.

$\cdots$

Our preliminary allocation of the purchase price, based on the estimated fair values of the assets acquired and liabilities assumed on the close date, were as follows:

(In millions)

Assets:

Accounts receivable

$\$$

Other current assets

Property and equipment

Intangible assets

Goodwill

Other long-term assets

Total assets acquired

Liabilities:

Other current liabilities

Deferred revenue

Long-term deferred tax liabilities

Other long-term obligations

Total liabilities assumed

Total purchase price

$\$$

Preliminary identified intangible assets and their respective useful lives, as of August 1, 2016, were as follows:

(In millions, except for useful lives)

Customer relationships

Developed technology and patents

Finite-lived trade names

Product backlog

Total identified finite-lived intangible assets

In-process research and development

Total identified intangible assets

\begin{tabular}{|c|c|c|}
\hline \multicolumn{2}{|c|}{ Fair Value } & $\begin{array}{c}\text { Weighted-Average Estimated } \\
\text { Useful Life }\end{array}$ \\
\hline \multirow[t]{6}{*}{$\$$} & 844 & 7 years \\
\hline & 739 & 4.3 years \\
\hline & 4 & 2 years \\
\hline & 2 & 4 months \\
\hline & 1,589 & \\
\hline & 19 & $\mathrm{~N} / \mathrm{A}$ \\
\hline$\$$ & 1,608 & \\
\hline
\end{tabular}

${ }^{16}$ The Symantec Corporation 10-K filing for the year ended March 31, 2017 can be accessed at https://www.sec.gov/Archives/edgar/data/849399/000084939917000009/symc33117-10k.htm 
Table 1.

Sample selection and summary statistics.

Panel A: Sample selection

Deals in the proprietary dataset completed between 2009 and 2016 with identifiable intangible assets

Less: Deals with bidders that do not link to CRSP/Compustat

Less: Deals with bidders incorporated outside the U.S. or with ADRs listed in the U.S.

Less: Deals missing regression covariates

3

Total in-sample deals

2,980

Total in-sample firm-years

2,560

Panel B: Number of deals and average deal size in millions of U.S. dollars by the Fama-French 12 industry classification of the bidder

Purchase price in millions of

\begin{tabular}{lll} 
& $\mathrm{N}$ & U.S. dollars \\
\hline Consumer nondurables & 132 & 902.69 \\
Consumer durables & 56 & 213.04 \\
Manufacturing & 278 & 421.71 \\
Oil, gas, and coal extraction and products & 32 & $1,019.58$ \\
Chemicals and allied products & 59 & 739.04 \\
Business equipment & 1,028 & 365.91 \\
Telephone and television transmission & 92 & $1,055.51$ \\
Utilities & 18 & 806.86 \\
Wholesale, retail, and some services & 197 & 326.39 \\
Healthcare, medical equipment, and drugs & 350 & 808.82 \\
Finance & 438 & 509.47 \\
Other & 300 & 379.21 \\
\hline
\end{tabular}

Panel C: Deal level summary statistics for the full sample of 2,980 deals

\begin{tabular}{|c|c|c|c|c|}
\hline & Mean & $\mathrm{P} 25$ & $\mathrm{P} 50$ & P75 \\
\hline Purchase price in millions of U.S. dollars & 502.23 & 15.43 & 53.00 & 229.37 \\
\hline $\begin{array}{l}\text { Identifiable intangible assets as a percentage of purchase } \\
\text { price }\end{array}$ & 43.58 & 21.54 & 37.76 & 54.17 \\
\hline Goodwill as a percentage of purchase price & 52.90 & 32.88 & 50.00 & 67.85 \\
\hline
\end{tabular}

Panel A of this table reports the number of deals (that meet the definition of a business combination) at critical steps in the sample selection process and the total in-sample firm-years. We start with all deals in the proprietary dataset that closed between 2009 and 2016 with positive identifiable intangible assets. We then limit the sample to firms with acquiror-years identified in the CRSP/Compustat Merged file. After we remove deals missing the necessary regression covariates and with acquirors incorporated outside of the U.S. (i.e., FIC not equal to USA or ADRR not missing), we are left with 2,980 deals. We then aggregate deals within each acquiror firm-year, which results in a final sample of 2,560 firm-year observations. Panels B and C report descriptive statistics at the deal level for the 2,980 deals this study includes in its sample. 
Table 2.

Descriptive statistics for regression covariates.

\begin{tabular}{|c|c|c|c|c|c|c|c|c|}
\hline \multicolumn{9}{|c|}{ Panel A: Distributional characteristics } \\
\hline & $\begin{array}{l}\mathrm{N} \\
(1)\end{array}$ & $\begin{array}{l}\text { Mean } \\
\text { (2) }\end{array}$ & $\begin{array}{l}\text { S.D. } \\
\text { (3) }\end{array}$ & $\begin{array}{l}\text { Min } \\
(4)\end{array}$ & $\begin{array}{l}\text { P25 } \\
\text { (5) }\end{array}$ & $\begin{array}{l}\text { P50 } \\
(6)\end{array}$ & $\begin{array}{l}\text { P75 } \\
\text { (7) }\end{array}$ & $\begin{array}{l}\text { Max } \\
(8)\end{array}$ \\
\hline Price $_{i, t}$ & 2,560 & 34.008 & 31.310 & 1.160 & 11.580 & 24.960 & 45.830 & 166.400 \\
\hline$B V_{i, t}$ & 2,560 & 9.787 & 11.158 & -14.836 & 2.699 & 7.353 & 14.395 & 52.554 \\
\hline$N I_{i, t}$ & 2,560 & 1.153 & 1.934 & -3.540 & 0.004 & 0.801 & 1.983 & 8.835 \\
\hline Wasting_II $I_{i, t}$ & 2,130 & 0.510 & 1.054 & 0.000 & 0.051 & 0.155 & 0.460 & 7.028 \\
\hline DTech $_{i, t}$ & 1,247 & 0.429 & 0.720 & 0.000 & 0.052 & 0.150 & 0.426 & 3.726 \\
\hline Contract $_{i, t}$ & 1,406 & 0.327 & 0.732 & 0.000 & 0.016 & 0.067 & 0.259 & 4.232 \\
\hline Organic_II $I_{i, t}$ & 2,058 & 1.212 & 2.458 & 0.000 & 0.088 & 0.326 & 1.081 & 14.564 \\
\hline$C R_{i, t}$ & 1,776 & 0.884 & 1.661 & 0.000 & 0.071 & 0.258 & 0.817 & 9.242 \\
\hline Trade $_{i, t}$ & 1,364 & 0.432 & 1.039 & 0.000 & 0.017 & 0.071 & 0.289 & 5.889 \\
\hline$I P R D_{i, t}$ & 338 & 0.343 & 0.522 & 0.001 & 0.023 & 0.101 & 0.381 & 1.785 \\
\hline MostSI_II_Avg $g_{i, t}$ & 1,827 & 1.421 & 2.629 & 0.002 & 0.153 & 0.449 & 1.363 & 14.973 \\
\hline Other_II_- $\bar{A} v g_{i, t}$ & 2,087 & 0.487 & 0.980 & 0.000 & 0.037 & 0.141 & 0.435 & 5.968 \\
\hline MostSI_II_IndAvg ${ }_{i, t}$ & 1,852 & 1.413 & 2.597 & 0.002 & 0.153 & 0.446 & 1.383 & 14.973 \\
\hline Other_II_IndAvg ${ }_{i, t}$ & 2,080 & 0.488 & 0.998 & 0.000 & 0.037 & 0.142 & 0.433 & 5.968 \\
\hline Total_III & 2,560 & 1.437 & 2.871 & 0.009 & 0.148 & 0.416 & 1.314 & 18.315 \\
\hline Goodwill $_{i, t}$ & 2,560 & 2.015 & 3.985 & 0.002 & 0.202 & 0.616 & 1.950 & 25.086 \\
\hline
\end{tabular}

Panel B: Mix of assets that MostSI_II_IndAvg ${ }_{i, t}$ classifies as most likely to be strategically important by Fama-French 48 industry classification

\begin{tabular}{lllllll} 
Fama-French 48 & Percent & \multicolumn{5}{c}{ Percent strategic disaggregated by intangible asset class } \\
classification & strategic & DTech $_{i, t}$ & Contract $_{i, t}$ & $C_{i, t}$ & Trade $_{i, t}$ & IPRD $_{i, t}$ \\
\hline Agriculture & 0.36 & 0.00 & 0.09 & 0.18 & 0.00 & 0.09 \\
Food products & 0.41 & 0.00 & 0.05 & 0.15 & 0.21 & 0.00 \\
Candy \& soda & 0.27 & 0.18 & 0.00 & 0.09 & 0.00 & 0.00 \\
Beer \& liquor & 0.40 & 0.00 & 0.20 & 0.00 & 0.20 & 0.00 \\
Recreation & 0.52 & 0.08 & 0.00 & 0.24 & 0.20 & 0.00 \\
Entertainment & 0.42 & 0.00 & 0.13 & 0.23 & 0.06 & 0.00 \\
Printing \& publishing & 0.36 & 0.09 & 0.09 & 0.15 & 0.04 & 0.00 \\
Consumer goods & 0.37 & 0.05 & 0.02 & 0.14 & 0.16 & 0.00 \\
Apparel & 0.35 & 0.00 & 0.03 & 0.08 & 0.24 & 0.00 \\
Healthcare & 0.33 & 0.02 & 0.08 & 0.20 & 0.04 & 0.00 \\
Medical equipment & 0.34 & 0.18 & 0.01 & 0.09 & 0.00 & 0.05 \\
Pharmaceutical products & 0.39 & 0.10 & 0.06 & 0.04 & 0.00 & 0.19 \\
Chemicals & 0.31 & 0.05 & 0.05 & 0.18 & 0.02 & 0.01 \\
Rubber and plastic products & 0.19 & 0.00 & 0.00 & 0.06 & 0.00 & 0.13 \\
Construction materials & 0.39 & 0.03 & 0.04 & 0.24 & 0.07 & 0.00 \\
Construction & 0.34 & 0.01 & 0.04 & 0.23 & 0.06 & 0.00 \\
Steel works & 0.36 & 0.04 & 0.04 & 0.25 & 0.05 & 0.00 \\
Machinery & 0.41 & 0.07 & 0.04 & 0.22 & 0.08 & 0.00 \\
Electrical equipment & 0.38 & 0.04 & 0.05 & 0.22 & 0.05 & 0.01 \\
Automobiles and trucks & 0.31 & 0.04 & 0.10 & 0.14 & 0.03 & 0.00 \\
\hline
\end{tabular}


Table 2. (continued)

\begin{tabular}{|c|c|c|c|c|c|c|}
\hline \multirow{2}{*}{$\begin{array}{l}\text { Fama-French } 48 \\
\text { Classification }\end{array}$} & \multirow{2}{*}{$\begin{array}{l}\text { Percent } \\
\text { strategic }\end{array}$} & \multicolumn{5}{|c|}{ Percent classified as strategic by asset class } \\
\hline & & $D T e c h_{i, t}$ & Contract $_{i, t}$ & $C R_{i, t}$ & Trade $_{i, t}$ & $I P R D_{i, t}$ \\
\hline Aircraft & 0.46 & 0.00 & 0.17 & 0.25 & 0.04 & 0.00 \\
\hline $\begin{array}{l}\text { Shipbuilding and railroad } \\
\text { equipment }\end{array}$ & 0.33 & 0.00 & 0.06 & 0.17 & 0.11 & 0.00 \\
\hline Defense & 0.33 & 0.06 & 0.00 & 0.22 & 0.06 & 0.00 \\
\hline $\begin{array}{l}\text { Non-metallic and industrial } \\
\text { Metal mining }\end{array}$ & 0.46 & 0.00 & 0.23 & 0.15 & 0.00 & 0.08 \\
\hline Petroleum and natural gas & 0.39 & 0.00 & 0.07 & 0.24 & 0.05 & 0.02 \\
\hline Utilities & 0.39 & 0.00 & 0.06 & 0.29 & 0.03 & 0.00 \\
\hline Communication & 0.41 & 0.05 & 0.12 & 0.23 & 0.01 & 0.00 \\
\hline Personal services & 0.44 & 0.00 & 0.20 & 0.13 & 0.11 & 0.00 \\
\hline Business services & 0.37 & 0.12 & 0.04 & 0.19 & 0.02 & 0.00 \\
\hline Computers & 0.39 & 0.19 & 0.03 & 0.16 & 0.00 & 0.01 \\
\hline Electronic equipment & 0.36 & 0.18 & 0.02 & 0.13 & 0.01 & 0.03 \\
\hline $\begin{array}{l}\text { Measuring and control } \\
\text { equipment }\end{array}$ & 0.39 & 0.16 & 0.06 & 0.16 & 0.00 & 0.00 \\
\hline Business supplies & 0.37 & 0.01 & 0.09 & 0.17 & 0.09 & 0.00 \\
\hline Transportation & 0.33 & 0.00 & 0.07 & 0.26 & 0.00 & 0.00 \\
\hline Wholesale & 0.36 & 0.02 & 0.03 & 0.25 & 0.06 & 0.00 \\
\hline Retail & 0.38 & 0.03 & 0.05 & 0.14 & 0.16 & 0.00 \\
\hline $\begin{array}{l}\text { Restaurants, hotels, \& } \\
\text { motels }\end{array}$ & 0.29 & 0.00 & 0.18 & 0.00 & 0.11 & 0.00 \\
\hline Banking & 0.15 & 0.02 & 0.05 & 0.07 & 0.01 & 0.00 \\
\hline Insurance & 0.38 & 0.03 & 0.14 & 0.20 & 0.01 & 0.00 \\
\hline Trading & 0.32 & 0.06 & 0.05 & 0.15 & 0.06 & 0.01 \\
\hline Almost nothing & 0.40 & 0.02 & 0.07 & 0.29 & 0.02 & 0.00 \\
\hline
\end{tabular}

This table reports descriptive statistics for the regression covariates in this study. Panel A only reports distributional characteristics on observations with positive values for Wasting_II $I_{i, t}$.DTech $h_{i, t}$, Contract $t_{i, t}$,Organic_II $I_{i, t}$ CR $R_{i, t}$, Trade $_{i, t}$, IPRD $D_{i, t}$, MostSI_II_Avg $g_{i, t}$ Other_II_Avg $g_{i, t}$, MostSI_II_IndAvg $g_{i, t}$, and Other_II_IndAvg $g_{i, t}$. Panel B reports the percentage of identifiable intangible assets that MostSI_II_IndAvg ${ }_{i, t}$ classifies as strategic by Fama-French 48 classification and intangible asset class. For example, in the agriculture industry, MostSI_II_IndAvg $g_{i, t}$ classifies $36 \%$ of the total number of identifiable intangible assets acquired as most strategically important. In addition, $9 \%$ (18\%, 9\%) of the total number of identifiable intangible assets acquired are classified as most strategically important and contractual (customer- related, in-process research and development). Note that the sum of $9 \%, 18 \%$, and $9 \%$ is 36\%. MostSI_II_IndAvg $g_{i, t}$ is the magnitude of identifiable intangible assets that, when scaled by total assets acquired, are greater than the mean identifiable intangible asset scaled by total assets acquired within the same Fama-French 48 industry classification. MostSI_II_IndAvg $g_{i, t}$ is set equal to missing for Fama-French 48 industry classifications with less than ten identifiable intangible assets acquired in our sample. All other variable definitions are in Appendix A and all variables are winsorized at the $1^{\text {st }}$ and $99^{\text {th }}$ percentile. 
Table 3.

Correlation matrix.

\begin{tabular}{|c|c|c|c|c|c|c|c|c|c|}
\hline & & (1) & (2) & (3) & (4) & $(5)$ & (6) & (7) & (8) \\
\hline (1) & Price $_{i, t}$ & 1 & $0.541 *$ & $0.683 *$ & $0.159 *$ & $0.065^{*}$ & $0.046^{*}$ & $0.219^{*}$ & $0.154 *$ \\
\hline (2) & $B V_{i, t}$ & $0.445^{*}$ & 1 & $0.584 *$ & $-0.052 *$ & $-0.190 *$ & $0.076^{*}$ & $-0.110^{*}$ & $-0.086^{*}$ \\
\hline (3) & $N I_{i, t}$ & $0.659^{*}$ & $0.553 *$ & 1 & $0.066^{*}$ & $-0.097 *$ & $0.115 *$ & $0.116^{*}$ & $0.059^{*}$ \\
\hline (4) & Wasting_II $I_{i, t}$ & $0.250^{*}$ & $-0.089 *$ & $0.096^{*}$ & 1 & $0.529 *$ & $0.488 *$ & 0.026 & 0.012 \\
\hline (5) & DTech $_{i, t}$ & $0.199 *$ & $-0.133 *$ & 0.034 & $0.653 *$ & 1 & $-0.302 *$ & $0.238 *$ & $0.278^{*}$ \\
\hline (6) & Contract $_{i, t}$ & $0.142 *$ & 0.008 & $0.114 *$ & $0.693 *$ & -0.024 & 1 & $-0.222 *$ & $-0.239 *$ \\
\hline (7) & Organic_II $I_{i, t}$ & $0.276^{*}$ & $-0.171^{*}$ & $0.115^{*}$ & $0.313 *$ & $0.341 *$ & $0.088 *$ & 1 & $0.829^{*}$ \\
\hline (8) & $C R_{i, t}$ & $0.236^{*}$ & $-0.123^{*}$ & $0.102 *$ & $0.255^{*}$ & $0.352 *$ & 0.004 & $0.843 *$ & 1 \\
\hline (9) & Trade $_{i, t}$ & $0.170^{*}$ & $-0.137 *$ & $0.080 *$ & $0.202 *$ & $0.172 *$ & $0.109 *$ & $0.726^{*}$ & $0.391 *$ \\
\hline (10) & $I P R D_{i, t}$ & $0.125^{*}$ & $-0.068 *$ & -0.007 & $0.249 *$ & $0.267 *$ & $0.059 *$ & $0.220 *$ & 0.037 \\
\hline (11) & MostSI_II_Avg $g_{i, t}$ & $0.284 *$ & $-0.192 *$ & $0.107^{*}$ & $0.539 *$ & $0.420 *$ & $0.305 *$ & $0.872 *$ & $0.702 *$ \\
\hline (12) & Other_II_- $\bar{A} v g_{i, t}$ & $0.241 *$ & $-0.069 *$ & $0.123 *$ & $0.536^{*}$ & $0.464 *$ & $0.299 *$ & $0.593 *$ & $0.553 *$ \\
\hline (13) & MostSI_II_IndAvg ${ }_{i, t}$ & $0.291 *$ & $-0.189 *$ & $0.115^{*}$ & $0.575^{*}$ & $0.436^{*}$ & $0.325 *$ & $0.870 *$ & $0.713 *$ \\
\hline (14) & Other_II_IndAvg $g_{i, t}$ & $0.240^{*}$ & $-0.090^{*}$ & $0.109^{*}$ & $0.506^{*}$ & $0.473^{*}$ & $0.257^{*}$ & $0.631^{*}$ & $0.559^{*}$ \\
\hline (15) & Total_II $I_{i, t}$ & $0.316^{*}$ & $-0.179 *$ & $0.130^{*}$ & $0.634^{*}$ & $0.505^{*}$ & $0.351^{*}$ & $0.914^{*}$ & $0.761^{*}$ \\
\hline (16) & Goodwill $_{i, t}$ & $0.327 *$ & $-0.133^{*}$ & $0.154^{*}$ & $0.489 *$ & $0.392 *$ & $0.290 *$ & $0.747 *$ & $0.697^{*}$ \\
\hline
\end{tabular}

Continued next page 
Table 3. (continued)

\begin{tabular}{|c|c|c|c|c|c|c|c|c|c|}
\hline & & (9) & (10) & (11) & (12) & (13) & (14) & (15) & (16) \\
\hline (1) & Price $_{i, t}$ & $0.108^{*}$ & $0.041 *$ & $0.205^{*}$ & $0.167^{*}$ & $0.216^{*}$ & $0.167 *$ & $0.310^{*}$ & $0.357 *$ \\
\hline (2) & $B V_{i, t}$ & $-0.136^{*}$ & $-0.054^{*}$ & $-0.146^{*}$ & 0.015 & $-0.133^{*}$ & -0.010 & $-0.041 *$ & $0.048 *$ \\
\hline (3) & $N I_{i, t}$ & $0.053 *$ & -0.035 & $0.092 *$ & $0.126^{*}$ & $0.102 *$ & $0.114^{*}$ & $0.192 *$ & $0.242 *$ \\
\hline (4) & Wasting $I I_{i, t}$ & $0.091 *$ & $0.107^{*}$ & $0.262 *$ & $0.460^{*}$ & $0.278 *$ & $0.445^{*}$ & $0.503 *$ & $0.405^{*}$ \\
\hline (5) & $\mathrm{DTech}_{i, t}$ & $0.243 *$ & $0.244^{*}$ & $0.266^{*}$ & $0.311^{*}$ & $0.267 *$ & $0.318^{*}$ & $0.280 *$ & $0.165^{*}$ \\
\hline (6) & Contract $_{i, t}$ & $-0.117 *$ & $-0.148 *$ & $-0.049 *$ & $0.218^{*}$ & -0.036 & $0.196^{*}$ & $0.142 *$ & $0.183 *$ \\
\hline (7) & Organic $I I_{i, t}$ & $0.628 *$ & $0.154 *$ & $0.595 *$ & $0.444^{*}$ & $0.596^{*}$ & $0.463 *$ & $0.753 *$ & $0.544 *$ \\
\hline (8) & $C R_{i, t}$ & $0.486^{*}$ & $-0.079 *$ & $0.431 *$ & $0.454^{*}$ & $0.452 *$ & $0.441 *$ & $0.589 *$ & $0.483 *$ \\
\hline (9) & Trade $_{i, t}$ & 1 & $-0.082 *$ & $0.331 *$ & $0.475^{*}$ & $0.328 *$ & $0.487 *$ & $0.468 *$ & $0.357 *$ \\
\hline (10) & $I P R D_{i, t}$ & -0.001 & 1 & $0.146^{*}$ & 0.017 & $0.132 *$ & $0.053 *$ & $0.118 *$ & -0.034 \\
\hline (11) & MostSI II $A v g_{i, t}$ & $0.608 *$ & $0.279 *$ & 1 & -0.028 & $0.911 *$ & 0.036 & $0.704 *$ & $0.348 *$ \\
\hline (12) & Other II $\bar{A} v g_{i, t}$ & $0.479 *$ & $0.089 *$ & $0.398^{*}$ & 1 & $0.042 *$ & $0.899 *$ & $0.505^{*}$ & $0.604 *$ \\
\hline (13) & MostSI_II_IndAvg ${ }_{i, t}$ & $0.595 *$ & $0.254 *$ & $0.967 *$ & $0.463 *$ & 1 & -0.005 & $0.717 *$ & $0.370 *$ \\
\hline (14) & Other_II IndAvg & $0.525^{*}$ & $0.177 *$ & $0.483^{*}$ & $0.882 *$ & $0.439 *$ & 1 & $0.512 *$ & $0.592 *$ \\
\hline (15) & Total $I I_{i, t}$ & $0.658 *$ & $0.260 *$ & $0.936^{*}$ & $0.667 *$ & $0.947 *$ & $0.686^{*}$ & 1 & $0.743 *$ \\
\hline (16) & Goodwill $_{i, t}$ & $0.508^{*}$ & $0.091 *$ & $0.663^{*}$ & $0.720 *$ & $0.687^{*}$ & $0.696^{*}$ & $0.792 *$ & 1 \\
\hline
\end{tabular}

This table reports Pearson (Spearman) pairwise correlation coefficients in the bottom (top) triangle. * indicates statistically different from zero at the $5 \%$ level based on two-tailed tests. Variable definitions are in Appendix A and all variables are winsorized at the $1^{\text {st }}$ and $99^{\text {th }}$ percentile. 
Table 4.

Wasting versus organically replaced price-level OLS regressions.

\begin{tabular}{|c|c|c|c|c|}
\hline DV: Price $_{i, t}$ & $\begin{array}{l}\text { (1) Baseline } \\
\text { analysis that } \\
\text { aggregates all } \\
\text { identifiable } \\
\text { intangible assets } \\
\text { into one variable }\end{array}$ & $\begin{array}{l}\text { (2) Wasting } \\
\text { versus } \\
\text { organically } \\
\text { replaced } \\
\text { comparison }\end{array}$ & $\begin{array}{l}\text { (3) Sensitivity } \\
\text { test that } \\
\text { excludes } \\
\text { observations } \\
\text { with positive } \\
\text { IPRD }_{i, t}\end{array}$ & $\begin{array}{l}\text { (4) Sensitivity } \\
\text { test that } \\
\text { excludes } \\
\text { observations } \\
\text { with identifiable } \\
\text { intangible assets } \\
\text { other than IPRD } \\
\text { classified as } \\
\text { indefinite lived }\end{array}$ \\
\hline$B V_{i, t}$ & $\begin{array}{l}0.704 * * * \\
(7.46)\end{array}$ & $\begin{array}{l}0.695 * * * \\
(7.39)\end{array}$ & $\begin{array}{l}0.642 * * * \\
(6.71)\end{array}$ & $\begin{array}{l}0.727 * * * \\
(6.70)\end{array}$ \\
\hline$N I_{i, t}$ & $\begin{array}{l}7.965 * * * \\
(11.61)\end{array}$ & $\begin{array}{l}7.965 * * * \\
(11.59)\end{array}$ & $\begin{array}{l}7.957 * * * \\
(11.84)\end{array}$ & $\begin{array}{l}7.439 * * * \\
(9.03)\end{array}$ \\
\hline Total_II $I_{i, t}$ & $\begin{array}{l}1.773 * * * \\
(5.25)\end{array}$ & & & \\
\hline Wasting_II $I_{i, t}$ & & $\begin{array}{l}2.989 * * * \\
(4.04)\end{array}$ & $\begin{array}{l}2.586 * * * \\
(2.49)\end{array}$ & $\begin{array}{l}4.179 * * * \\
(4.25)\end{array}$ \\
\hline Organic_II $I_{i, t}$ & & $\begin{array}{l}1.457 * * * \\
(3.69)\end{array}$ & $\begin{array}{l}0.766^{* *} \\
(1.78)\end{array}$ & $\begin{array}{l}1.349 * * * \\
(2.55)\end{array}$ \\
\hline Goodwill $_{i, t}$ & $\begin{array}{l}1.156^{* * *} \\
(4.81)\end{array}$ & $\begin{array}{l}1.180 * * * \\
(4.95)\end{array}$ & $\begin{array}{l}1.375^{* * *} \\
(5.14)\end{array}$ & $\begin{array}{l}1.390 * * * \\
(4.89)\end{array}$ \\
\hline Year FE & Yes & Yes & Yes & Yes \\
\hline FF12-by-year FE & Yes & Yes & Yes & Yes \\
\hline Observations & 2,560 & 2,560 & 2,222 & 2,139 \\
\hline Adj. R-squared & 0.573 & 0.573 & 0.556 & 0.556 \\
\hline \multicolumn{5}{|c|}{ Tests for differences in coefficient magnitude (F-statistics with p-values in parenthesis): } \\
\hline $\begin{array}{l}\text { Wasting_II } I_{i, t}>\text { Organic_II } I_{i, t} \\
\text { (one-tailed test) }\end{array}$ & & $\begin{array}{l}3.78 * * \\
(0.026)\end{array}$ & $\begin{array}{l}2.99 * * \\
(0.042)\end{array}$ & $\begin{array}{l}6.98^{* * *} \\
(0.004)\end{array}$ \\
\hline $\begin{array}{l}\text { Organic } I I_{i, t}=\text { Goodwill }_{i, t} \\
\text { (two-tailed test) }\end{array}$ & & $\begin{array}{l}0.24 \\
(0.626)\end{array}$ & $\begin{array}{l}0.91 \\
(0.339)\end{array}$ & $\begin{array}{l}0.00 \\
(0.954)\end{array}$ \\
\hline
\end{tabular}

This table reports the results from OLS price-level regressions that analyze differences between wasting and organically replaced identifiable intangible assets. The regression results report coefficient point estimates with $t$ statistics in parenthesis. Standard errors are clustered at the firm level and *** $(* *, *)$ indicates statistically different from zero at the $1 \%(5 \%, 10 \%)$ level based on one-tailed tests. The dependent variable is Price $_{i, t}$ defined as acquiring firm stock price (per share), measured on the $63^{\text {rd }}$ trading day after the end of fiscal year $t$ (i.e., one quarter into a year with 252 trading days). All other variable definitions are in Appendix A. Wasting $I I_{i, t}$ is the sum of DTech ${ }_{i, t}$ and Contract $t_{i, t}$; Organic_II $I_{i, t}$ is the sum of $C R_{i, t}$, Trade $_{i, t}$, and IPRD $D_{i, t}$. All regression covariates are winsorized at the $1^{\text {st }}$ and $99^{\text {th }}$ percentiles. 
Table 5.

Strategic importance price-level OLS regressions.

\begin{tabular}{|c|c|c|}
\hline DV: Price $_{i, t}$ & $(1)$ & $(2)$ \\
\hline$B V_{i, t}$ & $\begin{array}{l}0.711 * * * \\
(7.43)\end{array}$ & $\begin{array}{l}0.700 * * * \\
(7.27)\end{array}$ \\
\hline$N I_{i, t}$ & $\begin{array}{l}7.942 * * * \\
(11.48)\end{array}$ & $\begin{array}{l}7.977 * * * \\
(11.39)\end{array}$ \\
\hline MostSI_II_Avg $g_{i, t}$ & $\begin{array}{l}1.854 * * * \\
(5.24)\end{array}$ & \\
\hline Other_II_Avg $g_{i, t}$ & $\begin{array}{l}0.313 \\
(0.32)\end{array}$ & \\
\hline MostSI_II_IndAvg $g_{i, t}$ & & $\begin{array}{l}1.822 * * * \\
(4.94)\end{array}$ \\
\hline Other_II_IndAvg $g_{i, t}$ & & $\begin{array}{l}0.507 \\
(0.57)\end{array}$ \\
\hline Goodwill $_{i, t}$ & $\begin{array}{l}1.412 * * * \\
(5.04)\end{array}$ & $\begin{array}{l}1.391 * * * \\
(5.32)\end{array}$ \\
\hline Year FE & Yes & Yes \\
\hline FF12-by-year FE & Yes & Yes \\
\hline Observations & 2,560 & 2,540 \\
\hline Adj. R-squared & 0.573 & 0.575 \\
\hline \multicolumn{3}{|c|}{ Tests for differences in coefficient magnitude (F-statistics with one-tailed p-values in parenthesis) } \\
\hline MostSI_II $I_{i, t}>$ Other_II $I_{i, t}$ & $\begin{array}{l}2.59^{*} \\
(0.054)\end{array}$ & $\begin{array}{l}2.06^{*} \\
(0.076)\end{array}$ \\
\hline
\end{tabular}

This table reports the results of OLS price-level regressions and F-tests of differences in coefficient magnitude that test hypotheses related to the strategic importance of identifiable intangible assets. MostSI_II_Avg $g_{i, t}$ is the magnitude of identifiable intangible assets that, when scaled by total assets acquired, are greater than the mean identifiable intangible asset scaled by total assets acquired across the entire sample. MostSI_II_IndAvg $g_{i, t}$ is the magnitude of identifiable intangible assets that, when scaled by total assets acquired, are greater than the mean identifiable intangible asset scaled by total assets acquired within the same Fama-French 48 industry classification. MostSI_II_IndAvg $g_{i, t}$ is set equal to missing for Fama-French 48 industry classifications with less than ten identifiable intangible assets acquired in our sample. This results in a reduced sample of 2,540 firm-year observation in column (2). Standard errors are clustered at the firm level and $* * *(* *, *)$ indicates statistically different from zero at the $1 \%(5 \%, 10 \%)$ level based on one-tailed tests. The regression results report coefficient point estimates with $t$-statistics in parenthesis. In every column, the dependent variable is Price $_{i, t}$ defined as acquiring firm stock price (per share), measured on the $63^{\text {rd }}$ trading day after the end of fiscal year $t$ (one quarter into a year with 252 trading days). All variables are winsorized at the $1^{\text {st }}$ and $99^{\text {th }}$ percentiles. Variable definitions are in Appendix A. 
Table 6.

Cross-sectional price-level OLS regressions that partition the economic characteristics of wasting and organically replaced intangibles across strategic importance.

\begin{tabular}{lll}
\hline DV: Price $_{i, t}$ & $(1)$ MostSI_II_Avg & $(2)$ MostSI_II_IndAvg \\
\hline$B V_{i, t}$
\end{tabular}

This table reports the results of OLS price-level regressions and F-tests for differences in coefficient magnitude related to the interaction between wasting, organically replaced, and the most strategically important identifiable intangible assets. Columns (1) and (2) use the variables MostSI_II_Avg $g_{i, t}$, and MostSI_II_IndAvg $g_{i, t}$ to distinguish between the most and least strategically important identifiable intangible assets. MostSI_II_Avg $g_{i, t}$ (MostSI_II_IndAvg $g_{i, t}$ ) classifies identifiable intangible assets as most strategically important when their magnitude scaled by total assets acquired are greater than the mean identifiable intangible asset scaled by total assets acquired across the entire sample (within the same Fama-French 48 industry classification), and least strategically important otherwise. MostSI_II_IndAvg $g_{i, t}$ is set equal to missing for Fama-French 48 industry classifications with less than ten identifiable intangible assets acquired in our sample. This results in a reduced sample of 2,540 firm-year observations in column (2). In columns (1) and (2), MostSI\&Wasting ${ }_{i, t}$ (Other_II\&Wasting ${ }_{i, t}$ ) is equal to the magnitude of developed technology and contractual identifiable intangible assets classified as most (least) strategically important by MostSI_II_Avg $g_{i, t}$ and MostSI_II_IndAvg $g_{i, t}$, respectively. In columns (1), and (2), MostSI\&Organic $_{i, t}\left(\right.$ Other_II\&Organic $\left._{i, t}\right)$ is equal to the magnitude of customer-related, tradename, and in-process research and development identifiable intangible assets classified as most (least) strategically important by MostSI_II_Avg $g_{i, t}$ and MostSI_II_IndAvg $g_{i, t}$, respectively. Standard errors are clustered at the firm level and *** (**, *) indicates statistically different from zero at the $1 \%(5 \%, 10 \%)$ level based on one-tailed tests. The regression results report coefficient point estimates with $t$-statistics in parenthesis. In every column, the dependent variable is Price $_{i, t}$ defined as acquiring firm stock price (per share), measured on the $63^{\text {rd }}$ trading day after the end of fiscal year $t$ (one quarter into a year with 252 trading days). All variables are winsorized at the $1^{\text {st }}$ and $99^{\text {th }}$ percentiles. Variable definitions are in Appendix A. 